\title{
Effects of Extreme Disturbance Events: From Ecesis to Social- Ecological-Technological Systems
}

\author{
Ariel E. Lugo* \\ International Institute of Tropical Forestry, USDA Forest Service, 1201 Calle Ceiba, Jardín Botánico sur, Río Piedras, Puerto Rico \\ 00926-1115, USA
}

\begin{abstract}
Ecologists addressed the effects of disturbances from the onset of the field by focusing on ecesis, which is the process by which organisms migrate and establish under the environmental conditions created by disturbances. Ecesis is the onset of succession, a self-organizing process whose nature, speed, and outcome depend in part on the outcomes of ecesis and the residual legacies remaining after disturbances. A by-product of succession after a disturbance is the reorganization of species dominance, or novelty. The degree of novelty in the outcome increases with the severity of the disturbance event. Initially, ecologists focused mostly on non-anthropogenic disturbances, but as human activity intensified and became a global force, more attention was given to the effects of anthropogenic disturbances on ecosystems. Today, anthropogenic and non-anthropogenic disturbances and their interactions are increasingly affecting ecosystems, particularly those exposed to extreme disturbance events. Extreme disturbance events are complex and low probability events composed of several disturbance forces that individually and in synergy affect different sectors of ecosystems, including the conditions that drive ecesis. I review the literature on disturbance research including the effects of extreme disturbance events on social-ecological-technological systems (SETSs). A SETS is an ecosystem defined by the
\end{abstract}

flow and accumulation of energy through the medium of organisms, constructed infrastructure, institutions, and their environment. Human intentions, values, and capacities are part of the functioning of SETS, and they can drive ecological processes as do non-anthropogenic forces. Moreover, human-directed activities after an extreme disturbance event affect whole landscapes. The passage of hurricane María over the Puerto Rico SETS established that extreme disturbance events are of such power and complexity that they can influence the level and kind of relationship between humans and the environment, including the structure and species composition of the ecological systems within SETS. However, extreme disturbance events such as hurricanes have not changed the successional trajectory originally impulsed by anthropogenic disturbances. Thus, the species composition and functioning of novel forests in Puerto Rico are tied to economic activity in the social and technological sectors of SETS. It is no longer possible to interpret ecosystem functioning without considering the synergy between anthropogenic and non-anthropogenic extreme disturbances.

Key words: Anthropocene; energy analysis; hurricane María; large infrequent disturbances; novelty; SETS; succession.

Received 30 August 2019; accepted 18 January 2020;

published online 18 February 2020

*Corresponding author; e-mail: ariel.lugo@usda.gov 


\section{HighLights}

- The ecosystem concept allows for human activity as part of natural phenomena on Earth.

- Humans influence extreme events and together shape social-ecological-technological systems.

- Hurricane María was the most recent example of an extreme event shaping the social-ecologicaltechnological systems of Puerto Rico.

\section{INTRODUCTION}

The present level of human activity has measurable planetary effects and influences the conditions under which all ecosystems function. For example, the present atmosphere has a gaseous composition different from the atmosphere when the ecological sciences were developing, and has warmed since that time (Stocker and others 2014). Human activity is responsible for the movement of species across traditional biogeographic barriers, and humans move more nitrogen and phosphorus through their respective global biogeochemical cycles than the rest of the biota combined (Sterner and Elser 2002). These and other global effects of humans not only trigger anthropogenic disturbances, the loss of forest cover, and loss of species through extinctions, but also induce responses in the species composition of communities and generate novel environments. Part of the response of organisms and populations to this anthropogenic environmental change is the migration of species and their remixing into novel assemblages (Hobbs and others 2018; Lugo and others 2018). Novel microbial communities in landfills (Achmon and others 2018) are an example.

I will use the topic of extreme disturbance events (defined later) and their effects on social-ecological-technological systems (SETSs) to address the challenge of anthropogenic activity to ecosystems. A SETS is as an ecosystem defined by the flow and accumulation of energy through the medium of organisms, constructed infrastructure, institutions, and their environment. Social-ecological-technological systems, which include people and their activities, extend from urban to non-urban areas where the effects of humans are difficult to uncover. The ability of humans to garner fossil fuels and concentrate energy and material resources in response to their will and aspirations, makes them the dominant global force they are now and a necessary component and driver of ecosystem functioning. This ability is driven in part by tech- nology supported by burning of fossil fuels, which, paradoxically, has proven vulnerable to extreme disturbance events; as has been obvious with the failures of the power generating systems of California after extensive fire events or the failure of earthen dams in New Orleans during hurricane Katrina. The constructed infrastructure generated by the technology that supports human activity is a double-edged sword that requires attention when studying, analyzing, and designing sustainable social and ecological systems. Moreover, when technology fails, ecological systems are affected as happened after hurricane María and discussed below.

I take an ecological and a historical approach to show that ecologists have dealt with the effects of extreme disturbance events on ecosystems from the onset of the field but have done so by focusing on different aspects of the issue and using different terminology and different scales of analysis. Today, conditions created by anthropogenic forces challenge scientists to be as broad and as inclusive as they can in their approach to studies of the effects of extreme disturbance events on ecosystems. All types of ecosystems and as many scales of time and space as is technologically and intellectually possible are included.

\section{SuCCESSION AS A RESPONSE to Disturbances}

\section{Historical Context}

The field of ecology, including the modern understanding of ecosystems, developed during the first half of the twentieth century (Golley 1993; Kingsland 2005; Coleman 2010). The environmental setting in the USA during that time included the great depression, the dust bowl, extensive deforestation, overgrazing of rangelands, forest fires, and land degradation (Frederick and Sedjo 1991). Many of these environmental problems led to the establishment of government agencies such as the USDA Forest Service in 1905 and Soil Conservation Service in 1935. Their mission was the reversing of soil and land degradation through soil, vegetation, and land rehabilitation. Pioneer ecologists such as H.C. Cowles, J.E. Weaver, V.E. Shelford, H.A. Gleason, and F.E. Clements, known for their contributions to the development of successional theory in ecology, were engaged in dealing with the environmental disturbances of the time (Clements 1935). Clements (1935) considered ecology '...a point of view and a plan of attack' to be applied to '....all 
problems in which life and its environment are concerned' (p 342).

The focus of most ecological research at the time was on determining how vegetation growth and succession mitigated the effects of disturbances, rather than the effects of disturbances on vegetation. Animals were combined in the concept of bioecology (Clements and Shelford 1939) and thus included in the analysis of community change over time. Clements and other academicians interacted with government scientists and managers in land restoration and rehabilitation projects. From the outset, the two groups diverged in their approach, with government scientists favoring active management and academic ones focusing on allowing succession to proceed unimpeded, given that they assumed that the successional trajectory was predictable (Brock 2015).

\section{Causes of Succession}

Clements (1928) addressed the nature of anthropogenic and non-anthropogenic environmental causes that set succession in motion. Because of the complexity of successional processes, he understood that the causes were many and diverse, including physiographic or topographic, edaphic, climatic, and biotic causes that coincide with what today we call 'disturbances.' These causes resulted in bare or denuded areas on which the successional changes would unfold through the process of the establishment of organisms or ecesis. Ecesis included the adjustment of plants to 'a new home' (Clements 1928, p 63). Ecesis applies to both plants and animals (Clements and Shelford 1939), and it involves processes of germination (or birth), growth, and reproduction. Ecesis is the first step in the self-organization process that is the essence of succession. Fifty years later, Odum (1983) identified the order of the priorities of successional events from a systems point of view. The first priority was adaptation to physical requirements followed in order by growth of mass, development of storages, exchange with external systems, diversification, and temporal programs or phenology.

\section{Community Responses to Disturbances}

The pioneering ecological literature on succession describes the response of plants and animals to disturbances, documenting one aspect of resilience sensu Holling (1973), that is, the growth and selforganization after the disturbance event, but not addressing the force that caused the succession or its interaction with the affected system. An assumption at the time of Clements was that a non- anthropogenic disturbance provided the initial conditions of succession and ecologists described the mechanisms of species dispersal, colonization, establishment, and growth after the disturbance event and leading to a climax state. When dealing with anthropogenic disturbances, the notion of disclimax (disturbance climax) emerged in recognition of the different sequence of events and species establishment after these types of disturbances. In either case, the building of mass and storages through succession is one of the mechanisms that builds resilience in ecosystems, because these storages, or slow variables as they are now called, act as energy reserves required to overcome the effects of disturbances. For example, when a dry forest was subjected to repeated cutting disturbances events, the initial post-disturbance response did not vary, but the level of aboveground biomass achieved between events declined as belowground root storages were depleted (Ewel 1971). The energy cost of overcoming disturbances involves the cost of replacing structures, restoring organization, and maintaining high respiratory costs (Odum 1983). In the absence of sufficient time to replenish energy reserves, these costs deplete energy storage in slow variables and affect ecosystem development.

The extensive work of American ecologists resulted in complex schemes and vocabulary to describe community responses to disturbances through succession. Research also identified the different stages of vegetation succession (Clements 1928), particularly the notion that at some point in space or time, climax (mature state sensu Odum 1969) communities, different from successional ones, are established. Ecologists then asked: Was there a single or monoclimax, a polyclimax, or a landscape climax pattern? White (1979) provided arguments exposing the weaknesses of the climax concept and with a few modifications that enhanced the role of disturbances in environmental gradients, sided with the idea that there is a gradient from particularly predictable and frequent disturbances to relatively long-term disturbances' (Whittaker 1953, p 268).

From the beginning of the establishment of these ideas, conflict arose as to the nature and stability of climax communities, including the relative importance of external, exogenous, or allogeneic forces vs. internal, endogenic, or autogenic ones. Allogenesis is community change driven by environmental change, and autogenesis is community change driven by the properties of species present and their effects on the local environment (White 1979). Disturbance forces and their relevance to 
succession are normally considered external or allogenic factors, although several ecologists have pointed out that disturbances can also originate from within the affected system (White 1979; Sousa 1984; Pickett and White 1985).

Raup (1941) was among the first ecologists calling attention to the role of non-anthropogenic disturbances on boreal vegetation structure and species composition. He viewed external disturbance factors as part of the normal conditions of vegetation ( $p$ 36): 'It is possible that the role of a species in a formation of a young boreal community may be determined as much by [it's genetic variability] as by the interaction of the multitude of external environmental factors.' White (1979) asserted that the species composition of communities was a function of the disturbance regime. He also pointed out that many external disturbances to communities are not independent of endogenous properties of the communities themselves. That is, the interaction between external disturbance events and the endogenous properties of ecosystems is what defines the disturbance and its effects, and sometimes it is difficult to separate the external from the internal driving force. An example of this given by Sousa (1984) is tree falls. Tree falls can be caused by wind events, but also by the senescence of trees. In the absence of a windstorm, it is difficult to determine the fine line between tree falls due to external wind disturbance or from normal senescence.

\section{Characterizing Extreme Disturbance EvENTS}

The first obstacle to overcome in an analysis of the effects of extreme disturbance events on SETS is the diverse, and often contradictory, terminology used by the different social and natural sciences to address the same phenomena. In this review, I begin with the ecological and transition to the SETS.

\section{What is a Disturbance?}

'A disturbance is any relatively discrete event in time that disrupts ecosystem, community, or population structure and changes resources, substrate availability or the physical environment' (White and Pickett 1985, p 7). Disturbances as 'stressors' became the focus of research during the development of the field of radiation ecology in the 1950s and later in the 1980s with the development of 'stress ecology' (Barrett and Rosenberg 1981). A stressor is a force that drains potential energy from the affected system (Lugo 1978). Energy fluxes can contribute to ecosystem organization and growth or they can stress and disturb the system by causing disorder and draining its supply of potential energy (Figure 1). Holling (1996) used the term 'destabilizing' and 'stabilizing' forces to convey the same idea.

Considering disturbances as energy drains or as disordering agents reveals two types of disturbances to ecosystems. One is the physiological disturbance, that is, those stressors or disturbances that act through their effects on the metabolism of organisms (for example, Levitt 1980). The other is the mechanical disturbance, that is, those that affect ecosystems by disrupting structure, either living or dead. Whether the mechanism of effect is physiological or structural depends on the type of disturbance force.

White (1979) characterized disturbances as varying 'regionally and within one landscape as a function of topography and other site variables and are characterized by their frequency, predictability, and magnitude' (p 230). Pickett and others (1989, p 132), focusing attention on a hierarchical systems perspective, redefined disturbance to mean the change in the minimal structure caused by a factor external to the level of interest.' Their perspective was later incorporated in panarchy theory and the unpacking of disturbance forces (below).

Ionizing gamma radiation is a physiological stressor that can be quantified, and its effects related to the intensity and radiation dose. The dose of a disturbance force is its power or intensity, multiplied by the duration. Exposing different biotic systems to ionizing radiation established the stress response of a system to a stressor. Typically, biotic systems exhibit a range of tolerance to increased levels of stress, followed by a threshold and rapid decline with smaller increases in stress intensity. If the response of the system to the whole range of intensity of a stress factor is considered, as opposed to only the range under which it acts as a stressor, what is observed is that the response varies across the gradient from positive to negative or neutral. Positive responses of ecosystems to disturbances are well documented (Sousa 1984; Barrett and Rosenberg 1981; Pickett and White 1985). Sousa (1984) argued that it is hard to objectively decide where along a gradient of intensity a force becomes a disturbance, given that such gradient ranges from 'negligible' to 'extreme' depending upon the intensity of the force and the vulnerability of the affected system. He suggested that disturbances lie near one extreme of the contin- 


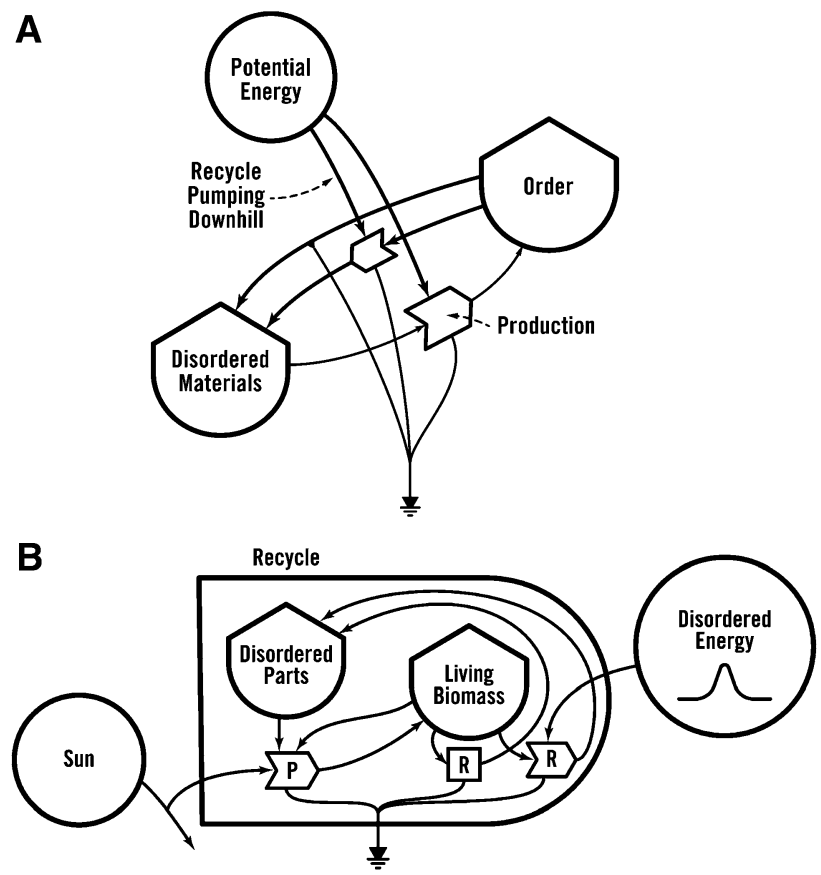

Figure 1. An energy flow diagram illustrating the role of energy in ordering and disordering materials in systems of all kinds $(\mathbf{A})$, and an illustration of the mechanism of energy action through the processes of production and respiration in ecosystems (B). The diagrams and symbols are based on Odum (1983). Photosynthesis is $P$ and respiration is $R$.

uum of non-anthropogenic perturbations that affect organisms.

The duration of a disturbance event is generally described as acute when it is a well-defined shortterm event, and chronic, when the event is long lasting. White (1979) considered chronic environmental factors as 'normal' to communities and acute ones as 'catastrophic.' Chronic environmental factors can become disturbances if an outside force exposed a system to an episode with a particular duration. For example, a cold snap with freezing temperatures that last from days to weeks acts as an acute disturbance to communities and ecosystems with adaptation to cold weather as it happens with mangroves in Florida and other warm temperate climates. Note that even if disturbances are defined by their episodic occurrence, their effects can be chronic or acute.

White (1979) defined frequency as the mean number of recurrences in a given time period. Predictability was defined as inversely related to the variation about mean recurrence interval. He found it difficult to define the magnitude of a disturbance because of the different characteristics that different disturbances had. For example, how could the magnitude of a wind event and that of a flood be compared? However, he observed that the time required for recovering the community to predisturbance conditions varied with the magnitude of the disturbance event. Energy analysis (below) partially overcomes the difficulty identified by White (1979).

The disturbance regime of a location is characterized by spatial distribution or areal extent; frequency or the mean number of events per time period; return interval, cycle, or turnover time (the inverse of frequency); turnover rate or rotation period (mean time needed to disturb an area equivalent to the defined study area); predictability measured by the variance in the mean time between disturbances; area disturbed or size; magnitude (composed of intensity of the force and severity of the effects); severity or effects on organisms; synergism or the effect on the occurrence of other disturbances (Sousa 1984; White and Pickett 1985). White and Pickett (1985) emphasize that for each of these descriptors it is of interest to have measures of central tendency and dispersion as well as frequency distributions.

Recently, Ratajczak and others (2018) have emphasized that focusing on mean values for drivers of disturbances and states of systems is insufficient to understand certain types of ecological changes that are becoming more prevalent on a biosphere under increased anthropogenic control. They called attention to abrupt changes in ecological systems and described multiple examples of the temporal functions associated with abrupt changes 
in the biota. The relevance of these observations is that we need more temporal resolution to properly assess ecosystem drivers and state variable responses to external forces. They further observed that the source of these abrupt changes was difficult to identify and understand, that is, that it was easier to observe the abrupt ecological change than it was to identify the causes of the interactions involved in the observed changes. To the degree that these abrupt changes are associated with extreme disturbance events, it may be possible to advance understanding of the phenomena if we advance in the analysis of the nature and effects of extreme disturbance events.

\section{Extreme Disturbance Events}

With global warming and climate change, there is an expectation that climatic disturbances will increase in intensity and frequency (Stocker and others 2014) as has been demonstrated for hurricane Sandy's flooding of the eastern coast of the USA (Lin and others 2016). These expected changes have led to the use of the term 'extreme events,' or 'extreme disturbance events' as I will call them, to describe what Turner and Dale (1998) defined as 'large infrequent disturbances' (LIDs). I defined extreme disturbance events as those in which any of its component disturbance forces and their interactions with affected systems have dimensions and responses that exceed the known range of variation expected of those parameters (Lugo 2018). This definition, based on Turner and Dale's (1998) definition of LIDs, makes explicit the interaction between the external forces of the disturbance event and the response of affected ecosystem components. A problem with this definition is the range of variation component, which is influenced by the length of available historical data needed to estimate an accurate probability of return for extreme events. Nevertheless, low probability extreme disturbance events are particularly significant to ecosystem functioning and development as well as to ecosystem management (Dale and others 1998) as shown for Mesoamerican tropical forests by Fernandez Vega and others (2017).

Turner and Dale (1998) suggested that LIDs could be identified from statistical distributions of spatial extent, intensity or duration, or by the perception of the event relative to a human scale or to the life span and attributes of the organisms in the affected ecosystems. The explosion of Mt Saint Helens (Dale and others 2005) or the passage of strong hurricanes (for example, category 3 to 5 in the Saffir-Simpson scale) over Caribbean islands could be accurately described as LIDs, or as extreme disturbance events, given their frequency of occurrence, intensity, area affected, and the response of affected ecosystems.

In spite of the practical identification of notable extreme events such as those discussed above, a more precise identification of what constitutes an extreme disturbance event is more difficult to achieve and is the subject of considerable study and debate because many extreme disturbance events are not recognized as such by those exposed to them either because their effects can be delayed or not immediately apparent. For example, extreme nocturnal heat events can increase mortality rates in cities without rising concern in the population as it happened in San Juan Puerto Rico in 2012 (Méndez Lázaro and others 2016). Moreover, an extreme drought may be in progress and almost ending before its effects are felt by affected anthropogenic and non-anthropogenic populations (Crausbay and others 2017). Chronic events like droughts are slow in developing and exert their influence through chains of events that begin with meteorological systems and cascades through hydrological, ecological, and social-technological ones (Crausbay and others 2017). If these events are to become more frequent, it is critical to increase our capacity to detect and anticipate them and their effects. Unfortunately, most of the ecological literature emphasizes the effects of extreme disturbance events but lacks sufficient information to describe the events with precision. Even a popular hypothesis to explain tropical biodiversity is termed 'the intermediate disturbance hypothesis' (Wilkinson 1999), but the hypothesis does not address the level at which a disturbance is intermediate' in strength. Without objective criteria for what 'intermediate' means, individual scientists are free to define 'intermediate' irrespective of the forces involved. A coordinated continental-scale network effort is needed to develop long-term spatial data on critical disturbance forces such as wind and sea-level rise (Hopkinson and others 2008).

Consistent with the need to precisely define and objectively measure the nature and intensity of disturbance forces, Johnson and Miyanishi (2007) argued that for the field of disturbance ecology to advance it has to focus on the relationship between disturbance forces, expressed in the physical sciences sense, and the affected parts of ecosystems. With a group of physical scientists who normally do not interact with ecologists, Johnson and Miyanishi presented the physical sciences approach for 
quantifying the forces of ecological disturbances. Similarly, national and international organizations (Klein Tank and others 2009; Peterson and others 2013; Grotjahn and others 2014) have developed criteria, procedures, and models to facilitate the quantification of extreme climatic events such as rainfall, temperature, fires, flooding, and other events. Zhang and others (2011) reviewed dozens of recommended extreme temperature and precipitation indices. These efforts have uncovered the obstacles to defining extreme events empirically, the complexity of the interactions between disturbance forces and affected systems, and the expanded role that human activity is having on the behavior and power of the disturbance forces.

McPhillips and others (2018) used a minimum variance method to quantify the similarity in extreme disturbance event language among various disciplines including ecological and social sciences as well as hydrology, and earth, engineering, and climate sciences. They found that ecologists and social scientists occupied the two extremes among disciplines. The complexities of the events and the communication challenges, particularly when human-dominated systems and different disciplines are involved, led McPhillips and others (2018) to conclusions about extreme disturbance events that partially differ from those traditionally accepted in the natural sciences.

The need to be cognizant of the language and meaning of other disciplines and to invest the required effort to communicate cross-disciplines, applies equally to all scientists engaged in the subject of extreme disturbance events. However, the notion in the social sciences of not conflating the effects of extreme events with the definition of the events is contrary to the ecological notion that extreme events are defined not only by characteristics of their forces, but also by the interaction with affected systems. McPhillips and others (2018) objected to using the effects of an event to define the event because one of the objectives of a SETS approach is to design resilient systems, which, if successful, would preclude observers from recognizing success after an extreme disturbance event. However, they suggested that the potential effects, not the effects themselves, on a system could be used as thresholds to define extreme disturbance events. Finally, although they could not come up with a single unifying definition of what an extreme disturbance event was, they suggested that those using the term should be explicit about what they mean, including noting the type of event, the affected SETS, the threshold used to characterize the event as extreme, and the rationale for the chosen threshold.

\section{Nature and Effects of Extreme Disturbance Events}

Extreme disturbances are complex events. The terminology used to identify them, such as 'hurricanes,' 'fires,' 'economic collapse,' 'war,' or 'drought,' is insufficient for advancing understanding about how they interact with, and affect, ecosystems, including SETS. Most extreme disturbance events involve more than one disturbance force and more than one interaction with different sectors of affected ecosystems, as illustrated for hurricane Hugo as it passed over the Luquillo Mountains of Puerto Rico (Table 1). A hurricane event can involve forces associated with rainfall, wind, and ocean surges and each of these forces add complexity to the event by causing tornados, floods, and landslides, which are also complex disturbance events (Lugo 2008, 2018). Thus, the effects of rainfall involve its mechanical effects on surfaces, its chemical potential in relation to solutes on downstream water bodies, and its influence on hydroperiods, soil stability, and gas exchange of soil organisms, to name a few. Moreover, the different forces that constitute an extreme disturbance event may have opposite effects on different sectors of an ecosystem. For example, when hurricane winds disrupt forest canopies and transport canopy mass to the forest floor, effects will vary from reductions in canopy flower and seed production with negative effects on organisms that are dependent on these resources, to positive effects on carnivorous animals whose food is now concentrated on the forest floor or on microbes with increased accessibility to labile organic matter available for decomposition (Brokaw and others 2012).

Because of the above, the understanding of how extreme disturbance events affect ecosystems requires a two-step analysis. The first step unpacks the disturbance event relative to all its component forces. The second step is the identification of the points of interaction between the disturbance forces and the affected ecosystem sectors or interfaces. Peters and others (2011) outlined the process of unpacking disturbance events and made crossecosystem comparisons. Several parameters require consideration when assessing the magnitude and effects of an individual disturbance force within a complex extreme disturbance event (Table 2). Predictability is not included for three reasons: First, the uncertainty associated with anthropogenic events diminishes the predictability crite- 
Table 1. Unpacking Hurricane Hugo and Its Interactions with Ecological Systems as It Passed Over the Luquillo Mountains of Puerto Rico (Scatena and Larsen 1991; Boose and others 1994)

\begin{tabular}{|c|c|c|c|c|c|}
\hline Parameter & Event & Wind & $\begin{array}{l}\text { Rainfall } \\
\text { intensity }\end{array}$ & Stream discharge $^{\mathrm{S}}$ & Storm waves \\
\hline $\begin{array}{l}\text { Point of } \\
\text { interaction }\end{array}$ & $\begin{array}{l}\text { Whole land- } \\
\text { scape }\end{array}$ & Forest canopy & Soil & Stream channel & Coral reefs/beach \\
\hline $\begin{array}{l}\text { Frequency } \\
\left(\mathrm{yr}^{*}\right)\end{array}$ & $50-60$ & 50 & 5 & $10-31$ & \\
\hline $\begin{array}{l}\text { Type of dis- } \\
\text { turbance }\end{array}$ & Atmospheric & Mechanical & Mechanical & Mechanical & Mechanical \\
\hline $\begin{array}{l}\text { Area } \\
\text { affected }^{\top} \\
\text { (ha) }\end{array}$ & $10^{6}$ & $10^{4}$ & $10^{*}$ & $10^{2}$ & $10^{3}$ \\
\hline Intensity & Category $3 * *$ & $166 \mathrm{~km} / \mathrm{h}$ & $\begin{array}{l}34 \text { to } \\
39 \mathrm{~mm} / \mathrm{h}\end{array}$ & 231 to $666 \mathrm{~m}^{3} / \mathrm{s}$ & 2.1 to $3.8 \mathrm{~m}$ \\
\hline Duration (h) & 10 & 4 & $1-3$ & $12-24$ & \\
\hline Main effect & $\begin{array}{l}\text { Landscape } \\
\text { disorder }\end{array}$ & $\begin{array}{l}\text { Loss of forest } \\
\text { canopy }\end{array}$ & Landslides & $\begin{array}{l}\text { Stream channel } \\
\text { modification }\end{array}$ & $\begin{array}{l}\text { Loss of coral reef structure, alteration } \\
\text { of beach profiles }\end{array}$ \\
\hline \multicolumn{6}{|c|}{$\begin{array}{l}\text { \$Varies with watershed. } \\
{ }^{*} \text { Frequency is one event in the number of years indicated. } \\
\text { T Estimated for stream channels and coastal line. } \\
\text { \$Area of rainfall-induced landslides. } \\
* * \text { Saffir-Simpson scale. } \\
\text { Empty cells mean information is unknown. }\end{array}$} \\
\hline
\end{tabular}

Table 2. Parameters that Describe an Individual Disturbance Force and Its Effects on Social-EcologicalTechnological Systems (SETS)

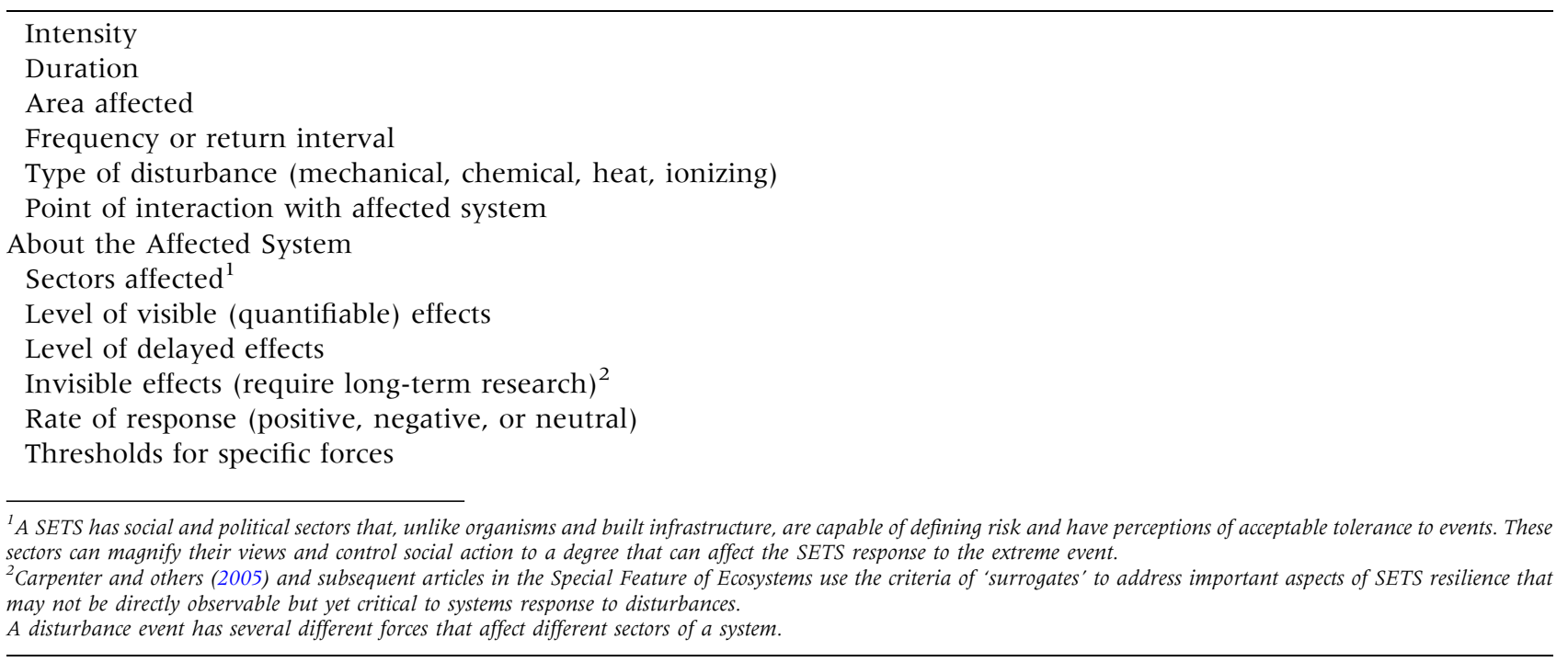

ria, which is associated with cyclic conditions. Second, there is a practical reason, since reliable long-term data on event histories are usually lacking. Third, events may appear unpredictable either mathematically or from the perspective of a particular point of view, but in reality, they can be anticipated or resolved by the evolutionary memory of populations or the self-organization process of ecosystems. Also, as footnoted in Table 2, when dealing with SETS, the social and political components become critical to the response of the SETS to events. This was demon- 
strated in Puerto Rico after hurricane María (Lugo 2019) when all sectors of the SETS, including the ecological, were affected by social and political actions.

Silver and others (1996) developed a matrix that identified ecosystem interfaces such as atmosphere-terrestrial, biotic-biotic, plant-soil, and terrestrial-hydrological interfaces in relation to key ecosystem processes in tropical forests. They described particularly high rates of ecological processes and concentration of biodiversity at the various interfaces. Disturbance forces acting on particular interfaces have specific effects on ecosystem functioning. For example, drought affects the composition and structure of dissolved and mineral-associated organic compounds of soils and affects the aerobic-anaerobic interface in subtropical wet forests. This changes microbial communities and influences carbon cycling and ecosystem functioning (Bouskill and others 2016). Ecologists can refine the analysis of extreme disturbance events by matching the disturbance force with the particular interface affected by the force. Lugo and others (1990) did such an analysis for disturbance forces affecting forested wetland ecosystems.

\section{Spatial Scale}

The spatial scale of extreme disturbance events is a consideration when addressing their effects. White and Pickett (1985) focused on patch dynamics as a relatively discrete spatial pattern to organize knowledge about the response of populations, communities, and ecosystems to disturbances. Specifically, they defined the spatial range of patches to mean $10^{-4}$ to $10^{6} \mathrm{~m}^{2}$. In the tropics, disturbance patch size was associated with the area of treefall gaps (Brokaw 1985), but Lugo and Zimmerman (2002) found that gap dynamics and the life-history characteristics of species associated with treefall gaps, even large ones, were different from those present after the passage of hurricanes. Hurricane-adapted species have different life-history characteristics from gap-adapted ones, in part because an extreme disturbance event has a larger footprint on the landscape (up to $10^{10} \mathrm{~m}^{2}$ ) than more frequent but less extensive disturbances. Scale is also important in the analysis of SETS. For example, based on an analysis of the governance of five large-scale social-ecological systems, Fleischman and others (2014) argued that scale made a difference in behavior, with smaller-scale systems behaving differently from large-scale ones.

The relation between area disturbed and number of disturbance events follows an exponential dis- tribution with many instances of small-sized events and few large-sized ones. The area affected by the disturbance is generally associated with its duration (longer-duration events affect larger areas than short-duration ones) and its severity (greater severity with the increased affected area). Extreme disturbance events can affect large areas although that does not mean that the intensity of the extreme disturbance event is homogeneous over all its area of influence. In fact, at a landscape scale, a LID creates heterogeneity due to variations of intensity throughout its affected area (Foster and others 1998). This landscape heterogeneity is of critical importance to landscape resiliency and delivery of ecosystem services, particularly as an insurance for maintaining the capacity to respond to uncertain future conditions (Turner and others 2013). Moreover, it is also possible to have an extreme event over a small scale such as a large landslide.

\section{Extreme Disturbance Events and Novelty}

An extensive literature links disturbance to evolution and adaptation in populations (for example, Stockwell and others 2003; Cox 2004; Thomas 2015; Bull and Maron 2016). Extreme disturbance events cause environmental heterogeneity both in time and in space, which can lead to differential reproduction and adaptation through natural selection and evolution. Sousa (1984) proposed that disturbances could affect subsequent generations of organisms through their effect on the genotype and the phenotype. White (1979, p 268) suggested that extreme disturbance events 'initiate a dramatic change in species composition' and that recurrent, frequent, and predictable disturbances could lead to selection for adaptation. He also recognized that anthropogenic disturbances may be totally new to vegetation and thus create a situation where local vegetation may not have adaptations to cope with the new conditions. In this case, anthropogenic disturbances would result in new selection pressures that favor accelerated evolution and a different assemblage of species. As novel conditions become more prevalent in a world dominated by human activity, ecological and evolutionary processes such as succession and evolution accelerate and lead to novel solutions and novelty in ecosystems with resilience to novel disturbance regimes (Radeloff and others 2015).

Odum (1983) suggested that systems that incorporate disordering energies into their functioning had an evolutionary advantage over those that did not. The mechanisms would be through evolution 
and adaptation, and the strategy is consistent with field observations of adaptation to disturbances at all scales of biotic organization. An example would be mangrove adaptations to salinity stress, at the cost of reduced plant diversity in mangrove ecosystems. Overcoming the disordering energy has an unavoidable energy cost, but adaptation to salinity and the positive contribution of subsidizing energy sources such as tides allow for mangrove ecosystem organization and growth. Ecologists have identified innumerable adaptations to disturbance forces (for example, evolution of carbon cycling traits in the Anthropocene, Monroe and others 2018). These adaptations exert their influence across all levels of biotic organization from the cellular to ecosystems and include physiological processes, life-history characteristics, community physiognomy, and rates of processes.

\section{Beyond Ecological Systems: Social- Ecological-Technological Systems}

The development of the ecosystem concept culminated with Evans (1956) who recognized the ecosystem as the basic functional unit in ecology. His definition of an ecosystem as the flow and accumulation of energy through the medium of organisms and their environment' (p 1127) has many conceptual advantages for the study and conservation of ecosystems including SETS. For example, his definition of the ecosystem eliminated the problem of delimiting the biotic boundaries or defining the size of ecosystems. This was an issue that Tansley (1935, p 299) addressed directly when he mentioned the term 'ecosystem' for the first time: 'These ecosystems, as we may call them, are of the most various kinds and sizes.' In spite of Evans definition, in 1993, Golley (p 34) pointed out that: '...ecologists tended to misuse the term 'ecosystem' as a more modern expression for the community concept or Clementsian complex organism and thus maintained the confusion that Tansley was trying to overcome.' Although Golley's observation still rings true with the general use of the term 'ecosystem,' the emergence of landscapelevel analysis of terrestrial cover coupled to the increased use of satellite images has expanded the geographic scale of analysis of ecosystems, particularly in relation to the role that humans play on landscapes (Ellis 2015). Ecosystems are open functional systems without limitation of size or geographic boundaries, whose artificial boundaries are established by the investigator, who must ac- count for energy, matter, and organism fluxes across them.

I adapted Evan's definition of 'ecosystem' to define SETS (above). As SETS are ecosystems, they are subject to the same biophysical laws and constraints that regulate all ecosystems. However, the presence of humans and institutions within SETS adds complexity to its structure and functioning, including the normative ideals of people as well as their capacity to expand and concentrate additional sources of energy and resources to purposefully direct the SETS in particular directions, including its ecological sector.

Tansley (1935, p 303) anticipated the important role played by human activity in emerging landscapes subjected to novel levels of disturbance: 'Regarded as an exceptionally powerful biotic factor which increasingly upsets the equilibrium of preexisting ecosystems and eventually destroys them, at the same time forming new ones of very different nature, human activity finds its proper place in ecology.' The proper place in ecology for humans can be approached from a SETS perspective, because it is becoming increasingly more difficult to isolate the social from the ecological or the technological when addressing the functioning of whole landscapes or of any of these three sectors of the landscape. Moreover, people and their activities are part of the phenomena that affect landscapes, and it is becoming untenable to treat the human element as if it was 'unnatural.' The SETS approach provides a framework for the objective study, analysis, and conservation of whole landscapes (Biggs and others 2015) that are increasingly affected by an urbanization trend that globally encompasses over half of the human population and is affecting at alarming rates the complex relationship between society and the environment (Romero-Lankao and others 2016).

Recent extreme disturbance events such as hurricane María over Puerto Rico (Lugo 2019), the 2018 fires in California (https://en.wikipedia.org/ w/index.php?title=2018_California_wildfires\&oldi $\mathrm{d}=890485287$ ), or the increased level of anthropogenically induced earthquake activity in central USA (Magnani and others 2017), all involve social, ecological, and technological causes and effects that call for a concerted analysis if we are to understand the historical path through which human civilization is traversing (Ellis 2015). A focus on the nature and effects of extreme disturbance events on SETS is as good as any for beginning the required transdisciplinary dialogue. Ecologists are challenged by SETS because they are required to join forces with social scientists and technologists to 
properly understand and manage the intertwined landscapes under human control, landscapes that have been shown to be highly vulnerable to extreme disturbance events (Markolf and others 2018).

\section{Energy Basis of Extreme Disturbance EVENTS}

Energy analysis partially overcomes the limitation identified by White (1979) regarding the comparison of different types of disturbances by using a common and objective unit (the joule) to evaluate the magnitude or intensity of disturbances and the cost to ecosystems of overcoming disturbances. Odum (1996) corrected the energy quality of the joule by introducing the concept of embodied energy or EMERGY. Odum calculated the energy of one kind required to produce another and expressed all energy flows in solar equivalents. For example, a joule of wood production by one hectare of spruce forest requires 3,846 joules of solar energy to produce; thus, the wood has an EMERGY value of 3,846 solar emjoules per joule produced. Odum and colleagues used EMERGY analysis to evaluate the energy flows of SETS systems (for example, Scatena and others 2002). I compared the power and total energy dose of different types of extreme disturbance events using uncorrected joules. The analysis showed the relative power of extreme winds $<$ extreme waves $>>$ extreme floods. Energy analysis can be applied to anthropogenic as well as non-anthropogenic systems, thus allowing the comparison of the responses to an extreme disturbance event by a SETS. Later I will discuss an energy analysis of the disturbance forces associated with hurricane María (Table 3).

\section{Resilience to Extreme Disturbance EvENTS}

A resilience focus, and resilience thinking, transcends ecological systems to also include SETS (Redman 2014). Gunderson and others (2010) identified three theoretical advances since Holling (1973) around the concepts embedded in the notion of 'resilience.' The first one is the expansion of the concept to many types of systems and applications as done by Romero-Lankao and others (2016) and Markolf and others (2018) for SETS. A second conceptual innovation is the adaptive cycle (Holling and Gunderson 2002). The adaptive cycle is a heuristic depiction of the cyclic order/disorder states of systems subjected to disturbances with opportunities for release or 'creative destruction,' and 'reorganization' or self-organization and reassembly into different system states. The third theoretical advancement in the development of the resiliency idea is the development of panarchy theory. Panarchy, or wholeness, is a way of thinking about systems and their interactions across multiple scales of space and time (Holling and others 2002). The panarchy idea builds on the hierarchical nature of all the systems in the universe, which is usually visualized as a bottom-up form of organization from subatomic particles to galaxies. Panarchy recognizes that systems respond to both bottom-up and top-down influences, with a nested and interconnected organization of adaptive cycles operating at different scales of time and space (Westley 2002).

Odum (1983) noted that events such as hurricanes or volcanic activity are part of planetary functioning involved with feedbacks at that scale, that is, redistributing heat and stabilizing climate in the case of hurricanes, and global biogeochemical cycles for volcanic activity. Such planetary processes become extreme disturbance events for systems organized at a smaller spatial scale such as affected landscapes or forests. This observation reveals the coupling of processes taking place at different levels of the hierarchical or panarchical organization of matter and systems within the planet. Processes or events with positive contributions to the functioning at one scale of organization may acutely or chronically disturb systems at smaller scales of organization, driving affected systems to invest resources for reorganization, acclimation, and adaptation.

The persistence of a system in spite of absorbing changes to its state and driving variables and parameters is a measure of its resilience and the speed of return to pre-disturbance conditions is its stability (Holling 1973). Carpenter and others (2001, p 777) clarified that resilience was a response of a particular system attribute to a particular force; thus, one has to ask resilience of 'what [variable or] system state to what perturbation [or force]' to be clear of what situation is being addressed. To paraphrase the title of the paper by Carpenter and others (2001), many statements about resilience assume that all components of an ecosystem are equally resilient to a variety of forces when in fact each component and attribute of an ecosystem has a particular level of resilience to different disturbance forces that need to be specified when speaking about resilience. This type of analysis was instrumental in leading to the unpacking of disturbance events and relating each 
Table 3. Power, Energy Intensity, and Energy Dose of Various Disturbance Forces of Hurricane María

\begin{tabular}{|c|c|c|c|}
\hline Disturbance force & $\begin{array}{l}\text { Power }(j / \\
\left.m^{2} s\right)\end{array}$ & $\begin{array}{l}\text { Energy } \\
\text { intensity }\end{array}$ & $\begin{array}{l}\text { Dose } \\
\qquad\left(\mathrm{j} / \mathrm{m}^{2}\right)\end{array}$ \\
\hline $\begin{array}{l}\text { Maximum sustained wind power }\left(36-74 \mathrm{~m} / \mathrm{s} \text { through } 100 \mathrm{~m}^{2} \text { for three }\right. \\
\text { minutes) }\end{array}$ & $\begin{array}{l}2.9 \mathrm{E} 6 \text { to } \\
2.5 \mathrm{E} 7\end{array}$ & $\begin{array}{l}0.8 \mathrm{E} 3 \text { to } 3.4 \mathrm{E} 3 \\
\left(\mathrm{j} / \mathrm{m}^{3} \text { air }\right)\end{array}$ & $\begin{array}{l}5.2 \mathrm{E} 8 \text { to } \\
4.5 \mathrm{E} 9\end{array}$ \\
\hline Island-wide area-weighted wind power over $24 \mathrm{~h}^{* *}$ & 3.1E4 & $\begin{array}{l}\text { 2.3E } 17 \\
\quad(\mathrm{j} / \mathrm{m} \text { vertical } \\
\text { air })\end{array}$ & 2.6E9 \\
\hline Maximum rainfall rate over $100 \mathrm{~m}^{2}$ for one hour & 4.9E7 & $\begin{array}{l}1.4 \mathrm{E} 6 \\
(\mathrm{j})\end{array}$ & $1.8 \mathrm{E} 11$ \\
\hline Total rainfall on mountains over $100 \mathrm{~m}^{2}$ for three days & $1.3 \mathrm{E} 10$ & $\begin{array}{l}5.1 \mathrm{E} 6 \\
(\mathrm{j})\end{array}$ & $3.5 \mathrm{E} 15$ \\
\hline $\begin{array}{l}\text { Chemical potential of maximum rainfall rate on mountains over } 100 \mathrm{~m}^{2} \\
\text { for one hour }\end{array}$ & $3.5 \mathrm{E} 4$ & $\begin{array}{r}3.5 \mathrm{E} 2 \\
(\mathrm{j} / \mathrm{s})\end{array}$ & $1.3 \mathrm{E} 6$ \\
\hline $\begin{array}{l}\text { Chemical potential of total rainfall on mountains over } 100 \mathrm{~m}^{2} \text { for three } \\
\text { days }\end{array}$ & $1.8 \mathrm{E} 1$ & $\begin{array}{r}1.8 \mathrm{E} 3 \\
(\mathrm{j} / \mathrm{s})\end{array}$ & 4.7E6 \\
\hline $\begin{array}{l}20,000 \text { landslides } \geq 20<15,000 \mathrm{~m}^{2} \text { and } 1 \mathrm{~m} \text { deep (actual depth range: } \\
0.1 \text { to } 30 \mathrm{~m} \text { ) }\end{array}$ & $1.7 \mathrm{E} 13^{* * *}$ & $\begin{array}{c}2.8 \mathrm{E} 19 \\
(\mathrm{j})\end{array}$ & $1.0 \mathrm{E} 16$ \\
\hline Waves $^{\dagger}$ & $\begin{array}{l}2.3 \mathrm{E} 5 \text { to } \\
3.0 \mathrm{E} 5\end{array}$ & & \\
\hline Annual Gross Domestic Product vs. Economic collapse of 2006-2016 & $\begin{array}{l}2.1 \mathrm{E} \text { vS. } \\
2.8 \mathrm{E}-2\end{array}$ & $\begin{array}{l}\text { 5.9E } 17 \text { vs. } \\
7.9 \mathrm{E} 16 \\
(\mathrm{j})\end{array}$ & $\begin{array}{l}\text { 6.8E7 vs. } \\
9.0 \mathrm{E} 6\end{array}$ \\
\hline Economic loss by María vs. Cumulative debt over 67 years & $\begin{array}{l}2.2 \mathrm{E} 2 \mathrm{vs} \text {. } \\
3.7 \mathrm{E}-2\end{array}$ & $\begin{array}{l}5.1 \mathrm{E} 17 \text { vs. } \\
7.0 \mathrm{E} 17 \\
(\mathrm{j})\end{array}$ & $\begin{array}{l}5.8 \mathrm{E} 7 \mathrm{vs} . \\
7.9 \mathrm{E} 7\end{array}$ \\
\hline $\begin{array}{l}\text { Average three-day power of solar energy at the top of the atmosphere } \\
\text { during September }{ }^{\dagger \dagger}\end{array}$ & $4.1 \mathrm{E} 2$ & & $3.6 \mathrm{E} 7$ \\
\hline \multicolumn{4}{|c|}{$\begin{array}{l}* \text { The corresponding value for category } 4 \text { hurricane Daisy was } 4.2 E 6 \text {. } \\
* * \text { Based on van Beusekom and others (2018). } \\
* * * \text { This analysis was based on Bessette-Kirton and others (2019) and unpublished data courtesy of those authors. Half the slides were smaller than } 20 \mathrm{~m}^{2} \text { and are not included } \\
\text { in this analysis. } \\
* * * * \text { The largest recorded landslide in Puerto Rico }\left(300,000 \mathrm{~m}^{3}\right) \text { had a power of } 5.8 E 1 \text { (Lugo 2018). } \\
\dagger \text { Personal communication (2018) Ernesto Diaz and Miguel Canals Silander, University of Puerto Rico at Mayagüez, PR). } \\
\dagger \dagger \text { Based on Colón Torres (2009). Annual solar energy dose is } 3.9 E 17 \mathrm{j} / \mathrm{m}^{2} . \\
\text { The methods for estimating energy values are from Odum (1996) and Lugo (2018). Empty cells mean data are not available. }\end{array}$} \\
\hline
\end{tabular}

disturbance force to particular locations within the affected ecosystem (Peters and others 2011). Resilience thinking also provides the theoretical basis for the development of policies that integrate conservation with novelty in social-ecological systems (Chapin and others 2013).

\section{Extreme Disturbance Events and SETS: Hurricane María Over Puerto Rico}

Puerto Rico is an example of an insular SETS that is highly dependent on outside sources of energy, materials, and technology. This dependency, plus its history of response to past extreme disturbance events, makes the Puerto Rico SETS a vulnerable one to extreme disturbance events. The September 19 to 21, 2017, passage of hurricane María over the island is an opportunity to apply systems-level analysis to the effects of an extreme disturbance event on a SETS with greater complexity than those studied so far (for example, Carpenter and others 2001; Gunderson and Pritchard 2002) because it includes a whole country with strong connections to support systems located outside the insular boundary.

To illustrate some of the aspects of a systemslevel analysis of the Puerto Rico SETS in relation to extreme disturbance events such as hurricane María, I first review information about the complexity of the extreme disturbance events involved, and then, I review available effects information from four perspectives: 1. The immediate effects of individual forces on sectors of the SETS. 2. The consequences of the immediate effects to SETS functioning. 3. How the hurricane effects on one sector of the SETS affected other sectors of SETS that otherwise would not have experienced such effects. 4. The longer-term temporal effects of ex- 
treme events on SETS with attention to how sequential extreme disturbance events set in motion whole trajectories of response that define the history of the country including its economy, landscapes, and ecological systems. In the discussion below, the supporting data for the social and technological effects of hurricane María on Puerto Rico are from Lugo (2019), unless otherwise indicated.

\section{The Complexity, Power, and Improbability of Hurricane María}

Two weeks before, the passage of hurricane María over Puerto Rico, hurricane Irma (category 5 in the Saffir Simpson scale) passed north of the north coast of the island, exposing the island's north coast to category 1 hurricane winds. After the passage of hurricane María, winter storm Riley, stationed off the coast of New England, generated heavy seas and wave action that significantly affected the north and western coasts of Puerto Rico. The timing of Irma and Riley complicated the interpretation of the effects of hurricane María, whose eye as it passed over the US Virgin Islands, had the lowest atmospheric pressure $(908 \mathrm{hPa})$ in the historical record for the Atlantic Ocean east of the Bahamas (Pasch and others 2018). Three small tornadoes were reported for Puerto Rico as a result of the passage of hurricane María, which was also notable for the rapid intensification that it exhibited on September 18. That day, its maximum wind speed rose from $148 \mathrm{~km} / \mathrm{h}$ to $269 \mathrm{~km} / \mathrm{h}$ in $24 \mathrm{~h}$, $74 \mathrm{~km} / \mathrm{h}$ faster than the highest value predicted by ten hurricane-tracking models (Pasch and others 2018). The human mortality was 4,645 people, believed to be an underestimate, with one-third of the mortality attributed to delayed or interrupted health care (Kishore and others 2018). Post-hurricane human migration was also substantial.

The combined winds of hurricanes Irma and María affected all $8800 \mathrm{~km}^{2}$ of Puerto Rico, dissipating an energy dose of $232 \mathrm{Pj} / \mathrm{m}$ of vertical air (Van Beusekom and others 2018). This energy dose is the equivalent of the energy released by the explosion of 55 megatons of TNT over Puerto Rico. Storms of the size and power of María have a return interval of about 1/86 years based on their wind speed. The wind power of these events was not distributed uniformly over the landscape due to their weakening during the 24 hours that the island was exposed to hurricane-strength winds and to the effects of island topography and aspect on wind power. As a result, more energy was dissipated on the southeastern and northern coastal zone and less on the southwest of the island (Van Beusekom and others 2018).

Keelings and Hernández Ayala (2019) concluded that the rainfall during hurricane María was the single largest maximum rainfall event since 1956, constituting an extreme outlier in the historical record. According to NASA's IMERG satellite measurements, hurricane María deposited $3.13 \mathrm{~km}^{3}$ of water over a three-day period as it moved from the island of Dominica and passed Puerto Rico. The rainfall associated with hurricane María measured by USGS station 50999961 near Caguas, Puerto Rico, was $953 \mathrm{~mm}$ between September 19 and September 21, and on September 20th, this station accumulated $254 \mathrm{~mm}$ in one hour, both are historic records. Most of central Puerto Rico received 381 to $508 \mathrm{~mm}$ of rainfall during those three days.

A map of annual exceedance probabilities for the worst-case 12-h rainfall prepared by the Office of Water Prediction of the National Weather Service (f tp://hdsc.nws.noaa.gov/pub/hdsc/data/aep/201709 _Maria/AEP_HurricaneMaria_September2017.jpg) shows the complexity of the rainfall exceedance pattern over the island's topography. Exceedance probabilities of $1 / 500$ to $1 / 200,1 / 1,000$ to $1 / 500$, and $<1 / 1000$ years predominate over exceedance probabilities of $<1 / 200$ year. The higher probability rainfalls were associated with the leeward aspects of the central mountains and the coastal karst alluvial plains. The lowest probability rainfall was associated with the windward aspects of the central mountain range, and the northeastern and northwestern sectors of the Island. Bessette-Kirton and others (2019) found that the maximum rainfall $(1,431 \mathrm{~mm})$ and mean mountain rainfall $(579 \mathrm{~mm})$ associated with the triggering of landslides during and after hurricane María were unprecedented in a 53-year record and, depending on how they were estimated, exceeded previous values by several fold.

Peak discharge of the major insular rivers ranged from 0.5 to 1.7 times the maximum previously recorded river discharges (Table 4). These historic peak discharges transported millions of cubic meters of sediments at rates that were 6.5 to 8.8 times the annual sediment transport of those rivers (Table 4).

The maximum surge level associated with hurricane María was 1.83 to $2.54 \mathrm{~m}$, the maximum wave height reached 7.6 to $6.4 \mathrm{~m}$ above mean sea level on Rincón and Fajardo, respectively, and the maximum coastal inundation level was 0.91 to $1.52 \mathrm{~m}$. The normal wave power regime for the coastal zones of Puerto Rico is in the order of E4 
Table 4. Ratio of Peak River Discharge Induced by Hurricane María to Maximum Historic Discharge of the River, Sediment Discharge, and Ratio of Total Sediment Discharge Caused by Hurricane María to Annual Average Sediment Discharge of Four Rivers Upstream from the Main Water Reservoirs in Puerto Rico

\begin{tabular}{llll}
\hline Reservoir & Discharge & \\
\cline { 2 - 4 } & Event/maximum historic & Sediment $\left(\mathrm{Mm}^{3}\right)$ & Event sediment/annual average sediment \\
\hline Dos Bocas & 1.34 & 2.1 & 6.53 \\
Caonillas & 0.95 & 2.1 & 8.45 \\
La Plata & 1.73 & 2.5 & 8.81 \\
Carraizo & 0.51 & 2.6 & 8.59
\end{tabular}

The maximum historic value is obtained from the record at the given gaging station. Values associated with the passage of hurricane Maria are identified by 'Event'. The source of data is from the United States Geological Survey, and Ferdinand Quiñones Marquez analyzed the data.

$\mathrm{j} \mathrm{m}^{-1} \mathrm{~s}^{-1}$ (Canals Silander and García Moreno 2019) and rose to $2.3 \mathrm{E} 5$ to $3 \mathrm{E} 5 \mathrm{j} \mathrm{m}^{-1} \mathrm{~s}^{-1}$ at the same locations during the passage of hurricanes Irma and María and winter storm Riley (Díaz and Canals, personal communication, 2018).

A conversion to common units of power and energy dose of the magnitudes of forces that affected Puerto Rico during the events associated with hurricane María (Figure 2) shows that the largest forces were associated with water power as opposed to wind power. More energy was dissipated moving rocks, debris, and sediments than knocking down infrastructure and trees. Also, the duration component of a disturbance force affects the ultimate energy load, or stress dose, on system components. For example, the power associated with economic losses was low relative to the power of physical forces affecting SETS. However, the dose of economic losses was several orders of magnitude higher than their power and ap-

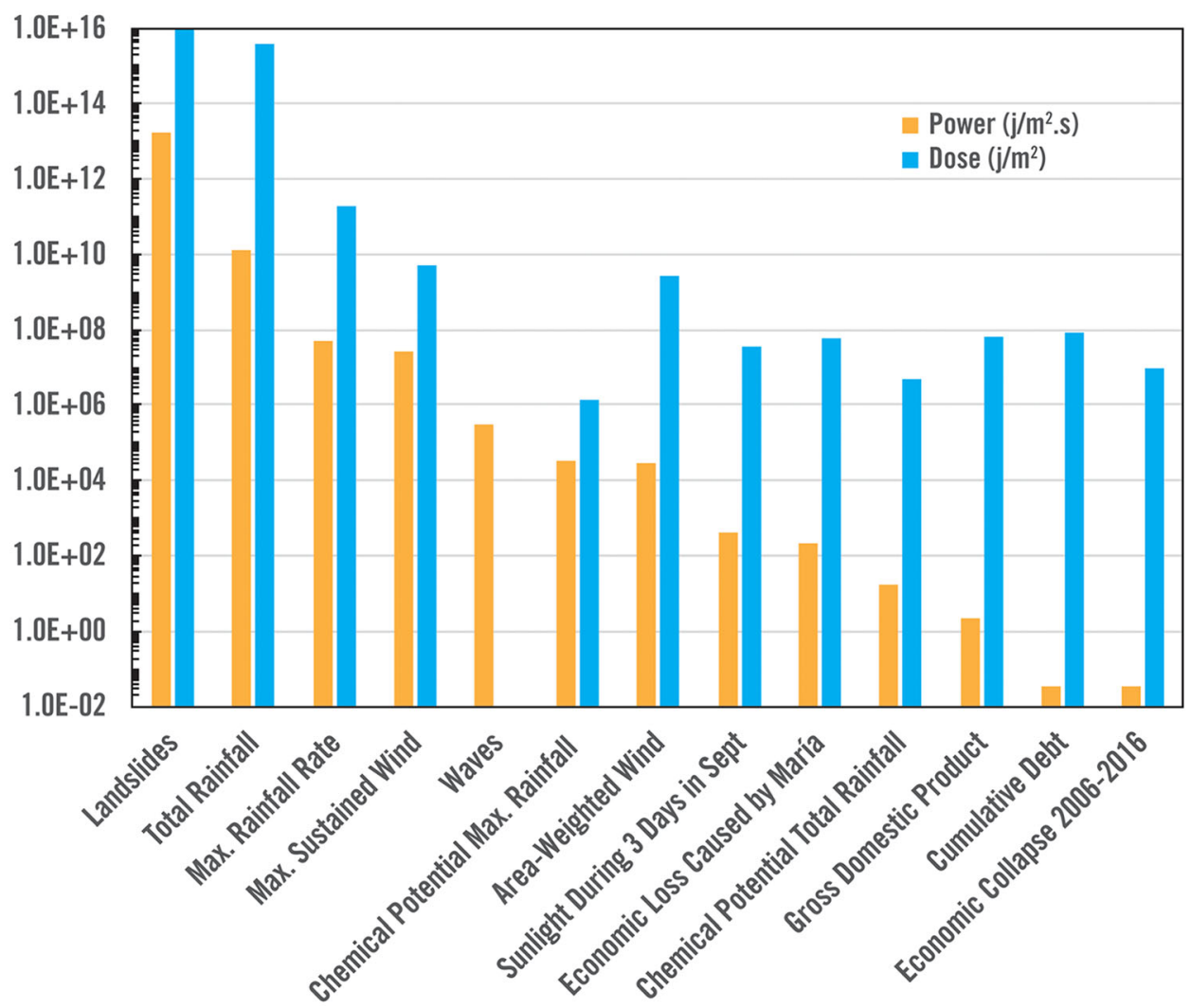

Figure 2. The power and dosage of several disturbance forces associated with hurricane María (including hurricane Irma and storm Riley). Solar energy input for the same period of time that hurricane María affected Puerto Rico is included. Table 3 and the text have more details. 
proached the dose of area-weighted wind. Similarly, the power of disturbance forces associated with María was much higher than the power of solar energy reaching Puerto Rico. However, the solar energy load, construed as a positive force for SETS, had the same order of magnitude over an annual cycle as the disturbance forces had over three days.

\section{Effects of Winds}

Wind power had significant effects on canopy cover, standing forest biomass, vegetation greenness, and ecosystem processes such as mass and nutrient fluxes and also significantly damaged the gray (constructed) infrastructure of the Island (Lugo 2019). Average top canopy height of the Dacryodes excelsa forest in the Luquillo Mountains declined by $67 \%$ after María (Nicholas Brokaw, University of Puerto Rico, personal communication May 16, 2019). Vegetation throughout the island was defoliated and the island acquired a brown color that contrasted with the greenness before the hurricanes (Hu and Smith 2018). Snapping of tree stems in the Luquillo Mountains was linearly related to wind speed $(y=0.405 x-10.759$; $R^{2}=0.9937$ ) based on repetitive measurements at the same location after hurricanes Hugo, Georges, and María (Uriarte and others 2019) and a range of wind speeds associated with those hurricanes that I obtained from NOAA. Because the winds from hurricane María were among the strongest on record, the level of tree snapping was proportionally higher than what had been measured before. Instantaneous tree mortality rates were high $(15 \%$, Uriarte and others 2019), but tree mortality rates are difficult to estimate after a hurricane due to the sprouting capacity of stems that appear dead but later regrow. Preliminary results from a Forest Inventory and Analysis systematic insular survey show that tree mortality increased from dry $(3.9 \%)$ to moist $(11.9 \%)$ to wet $(15.5 \%)$ forests with an insular average of $10.4 \%$ (Humfredo Marcano Vega, personal communication, September 12, 2019).

Winds felled about 90 and $80 \%$ of the telecommunication antennas and towers, respectively, affecting communications. Winds also knocked down most electrical transmission lines and electricity poles, which affected power transmission and all activities that depended on electricity, including most traffic lights. Roads and trails were cluttered with downed wood and solid wastes.

\section{Effects of Rainfall and River Discharge}

Flood and landside events associated with hurricane María changed topographic features of the island (both coastal and mountain areas), moved enormous quantities of sediments, sedimented water reservoirs, and changed river courses. Excessive rainfall caused historic floods and over 40,000 landslides in Puerto Rico (Bessette-Kirton and others 2019). The area of individual landslides after hurricane María was smaller than the area of landslides in the El Yunque quadrangle of the Luquillo Mountains after hurricane Hugo. This discrepancy in the area of individual landslides can probably be attributed to the granodiorite intrusions prevailing in the El Yunque quadrangle and the varied geological formations prevailing in the Central Mountains of Puerto Rico. In both studies, the granodiorite formation had a higher density of landslides than adjacent volcanic formations. Regardless of the area of landslides, roads and bridges were left impassable, isolating whole towns and communities.

\section{Effects of Waves and Ocean Surge}

The ocean surge and wave energy associated with the passage of hurricanes Irma and María and winter storm Riley affected the coast of Puerto Rico by changing beach profiles, removing structures, transporting coral reef materials to the land, and causing large piles of debris on the coastal zone. The structure of some coral reef communities was flattened, and dead corals were transported to beaches where they piled up. Most beaches, particularly in west-northwest, northcentral, and southeastern portions of the Island, lost elevation and had variable width changes (Barreto Orta and others 2019). Like in similar events in Australia, the direction of waves was as important as their height (Harley and others 2017). Ocean surge flooded coastal wetlands and resulted on massive tree mortality when ocean waters trapped inland were slow to recede. Ocean incursions on communities coupled with flood waters affected the contents inside structures and in many cases also destroyed vulnerable human dwellings.

\section{Consequences of the Effects}

The Puerto Rico SETS lost connectivity both internally and with the outside world. This isolation affected the flow of goods, services, and fuels, resulting in the depression of its economy and disruptions in the social order. For example, floods and landslides isolated communities and inter- 
rupted transportation and the capacity of the government to communicate and assist stranded communities. Also, insular communications, the electric power grid, and transportation systems all ceased to function as a result of wind effects and their built-in vulnerabilities. These failures had a high multiplier effect on other sectors of the SETS as the economy of the Island nearly reached a standstill. María was the third costliest hurricane in the US history costing the Puerto Rico economy $\$ 90$ billion (Pasch and others 2018), an energy loss equivalent to about 5.1E17 j over three days. For comparison, the public debt that led to the bankruptcy of the insular government reached \$123 billion, or about $7.0 \mathrm{E} 17 \mathrm{j}$, over 67 years; four orders of magnitude difference in terms of the power loss (Figure 2).

Winds dispersed organisms within the forest sector, which also experienced a massive transfer of canopy biomass to the forest floor. These events altered the long-term carbon and nutrient cycles of watersheds (Lugo 2008). Excessive rains exposed weaknesses in canalized streams and rivers when run-off exceeded canal designed criteria and flooded communities protected from floods of greater frequency than those associated with this extreme event. The outcome for SETS on the coastal zone was particularly challenging given the massive accumulation of rubble on the shoreline, where removal is expensive and beyond the capacity of government to remove it. Long stretches of useless beachfront property is one of the legacies of the combined effects of hurricanes Irma and María and storm Riley.

\section{Interactions Between Sectors of SETS}

The effects of hurricane María on ecological systems was exacerbated by the effects of the hurricane on the social and technological systems of Puerto Rico. The hurricane collapsed the power system and prevented social attention to water pumping stations. All machines and functions dependent on electrical power were immobilized. As a result, the water purification and distribution system, and the storm water management system failed because water pumping ceased throughout the Island. These failures of built infrastructure and management in the social and technological subsystem of SETS affected humans but also the ecological systems, particularly aquatic systems. Levels of water pollution in estuaries and protected areas rose significantly as used waters mixed with pluvial and rain waters. Technological systems failed to monitor these effects because those laboratories responsible for environmental monitoring were not functioning. Similarly, air pollution monitoring and the tsunami alert system also failed to operate post-hurricane. Laboratories and equipment were not functional, and humans could not gain access to their workstations.

The loss of canopy and leaf cover in urban vegetation affected the social-technological system by increasing the air temperature and lowering the relative humidity in the city. The temperature differential was greater than $3^{\circ} \mathrm{C}$ and urbanites were well aware that the city was warmer after the hurricane at a time when the city had no power to artificially cool indoor environments. The loss of vegetation due to winds, coupled to exposed soils due to poor land use, and the magnitude of the event, affected the water and sediment cycles of the island, which in turn affected costal systems, including coral reefs (Miller and others 2019).

The lack of electric power and its multiple effects on the functioning of a SETS that was fully dependent on fossil fuel generation of electricity, coupled with the absence of communications and transportation, paralyzed the functions of the governance of SETS, and it was up to individual human initiative and community action to address the recovery after the hurricane and provide help to the needy.

\section{Effects at Large Spatial and Historical Time Scales}

The regreening of vegetation after hurricane María was rapid as measured by the NDVI index from Landsat 8 satellite (Hu and Smith 2018). After the hurricane, native forests can quickly accumulate biomass and restore forest conditions and cycling processes (Scatena and others 1996). A longer time is required to restore animal population levels after the storm, as the recovery of pre-hurricane population levels varies with the diet and habitat requirement of the species (Brokaw and others 2012). For trees, long-term study and non-metric multidimensional scaling suggests that species assemblages' approach, but do not return to, conditions before the hurricane (Heartsill Scalley 2017). Extreme events generate novelty in the ecological sector of SETS.

In contrast to the self-organization and self-repair of the ecological systems within SETS, the social and technological infrastructure requires outside attention to be repaired and modified to face the next extreme disturbance event. This requires allocation of funds, energy, and time, as well as decisions through the governance system of the 


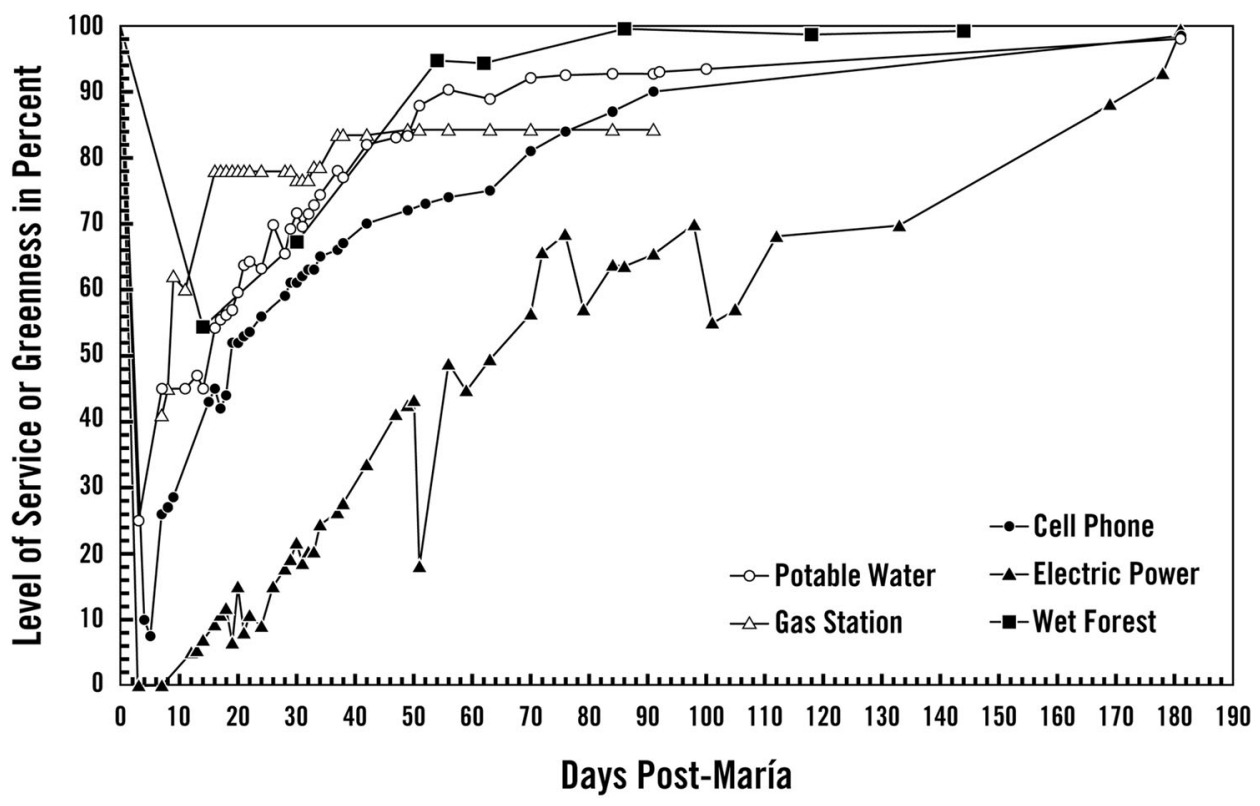

Figure 3. Recovery of various sectors of the Puerto Rico social-ecological-technological system after hurricane María (Lugo 2019). Román and others (2019) found that the recovery of the power generation reported here was faster than what they could assess from nighttime lights recorded by a NASA satellite.

SETS. The functioning of the social-technological subsystem introduces a lag in the repair process after the extreme event. This lag explains the contrast between the self-repair of the ecological sector and the repair of gray (constructed) infrastructure (Figure 3).

The analysis of the effects of extreme disturbance events on ecological systems such as the explosion of Mount St. Helens demonstrated the importance of legacies to the recovery of the ecological systems of that region (Dale and others 2005). Legacies are also important to the recovery of tropical forests after hurricanes (Lugo 2008) and contribute to forest resilience in light of changing disturbance regimes (Johnstone and others 2016). In social and technological systems, legacies include non-structural components such as knowledge and culture, and include laws, regulations, planning, and adaptive capacity. Grove and others (2018) show how legacies of the 1880s social injustices in Baltimore influence both the present and future sustainability of that SETS.

An analysis of the effects of hurricanes on the urban structures of Puerto Rico led Sepúlveda Rivera (2018) to observe that after the passage of each major hurricane over the island, there has been a major restructuring of the economy and resource allocation, designed to improve conditions after those events. In fact, the need for a restructuring of the economy after each extreme distur- bance event suggests that the previous solutions failed.

I noted that what Sepúlveda Rivera was observing in the urban sector, applied to all the Puerto Rico SETS, including the ecological sector. Extreme disturbance events appear to have steered the structure and functioning of the Puerto Rico SETS not by randomly affecting each subsystem but as a result of whole system response to events (Figure 4). Each sector of the SETS operates as a system with its own organization, functioning, and resilience capacity, that is, each sector has its own adaptive cycle. But they are open systems connected to other components of SETS and subjected to their influence as well as influencing them.

In the case of Puerto Rico, human activity over centuries has altered land cover (almost 100\% of the territory) and soil conditions (75\% of the territory) so dramatically that it affected the ecological process of ecesis island wide. This alteration of a landscape that was initially a forested landscape began by the establishing of low-intensity agricultural activity under the Spanish government and evolved into a monoculture of sugarcane after at the end of the nineteenth century when the island was exposed to a category 5 hurricane San Ciriaco and the military invasion by the Army of the United States of America. The agricultural land use established after the Hispanic-American War effectively deforested all Puerto Rico, but it succumbed to hurricanes San Felipe and San Ciprián 


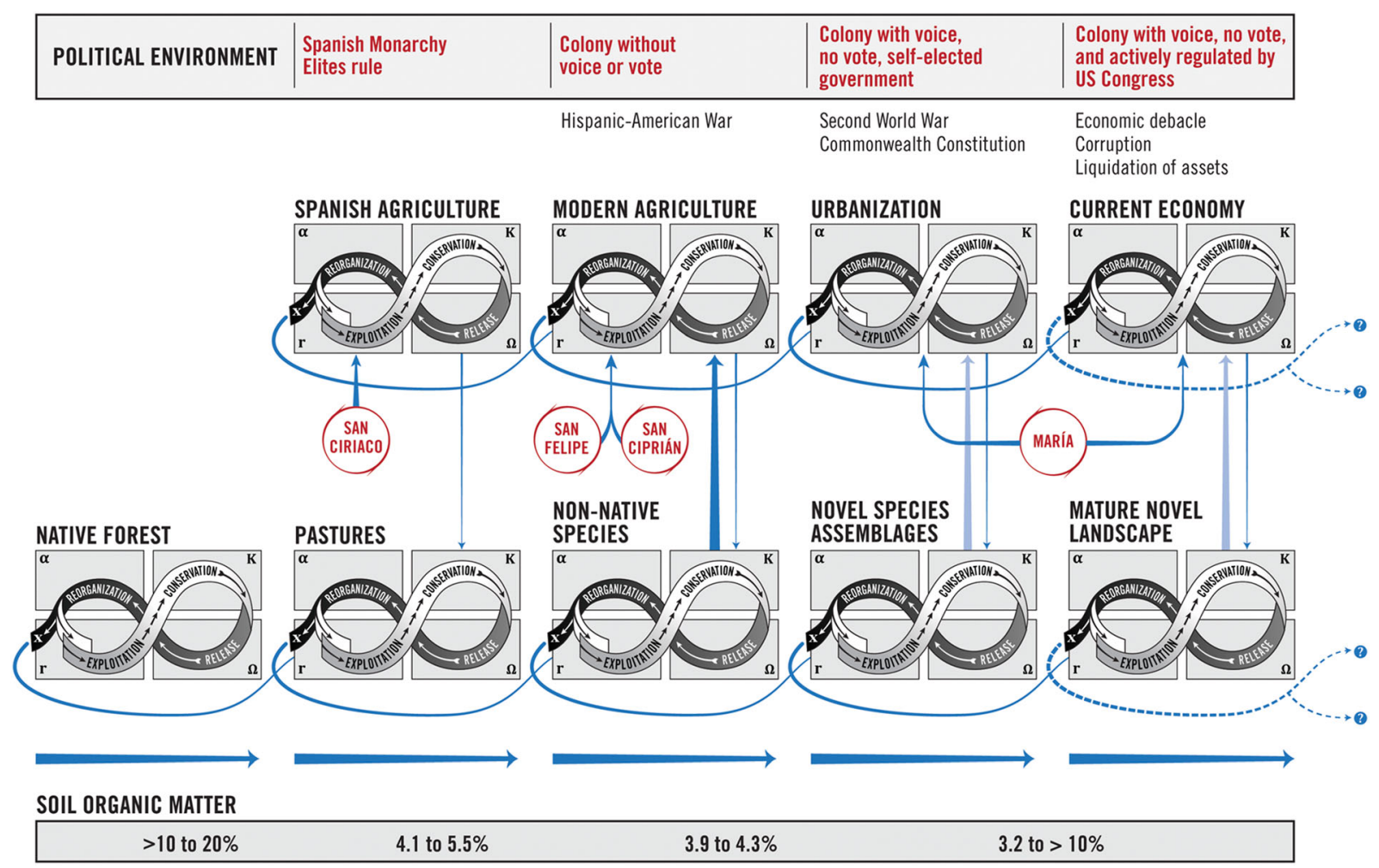

Figure 4. Historical panarchies of Puerto Rico in response to extreme (category 4 and 5 in the Saffir-Simpson scale) hurricane events (blue lines). Shown are time series for land cover (top) and vegetation from 1898 to 2017 (left to right). Each of these two subsystems has its own adaptive cycle, and they change and reorganize into a different state with another adaptive cycle in response to extreme events. The effect of land cover on vegetation is shown by the small arrowed line. This simplification is based on Figure 7.6 in Lugo (2019). Soil organic matter concentration is a proxy for soil conditions controlling ecesis of trees The data on soil organic matter concentration are from Weaver and others (1987) for novel forests in the 1980s, Roberts (1942) and Soil Conservation Service (1967) for pastures and agricultural soils in the 1930s to 1960s, and sources quoted in Lugo (2005) for mature native forests assumed to reflect soil conditions before deforestation. More details in the text.

between 1928 and 1932. After these two extreme disturbance events, the human population abandoned agricultural lands and moved to cities leading to an urbanization process that returned forests to abandoned agricultural lands.

Conditions for ecesis following intensive anthropogenic land use were different from those where humans had not deforested and degraded soils. This is illustrated in Figure 4 with values of organic matter concentration at different times through the twentieth century. Ecological legacies after these intensive uses were depleted, or as suggested by Johnstone and others (2016), a 'resilience debt' prevailed. Native species could not regenerate and colonize abandoned lands with degraded soils but introduced species could (Lugo and Abelleira Martínez 2018). The dominance of native tree species was relegated to those locations where human activity had less influence on soil conditions ( $25 \%$ of the territory), while introduced tree species colonized and dominated altered sites on $75 \%$ of the territory. Most insular forests are now novel forests (Lugo and Helmer 2004; Martinuzzi and others 2013) because of human activity.

The extreme disturbance events associated with hurricane María exposed the vulnerability of the land cover (urban sprawl) and economic activity that emerged after hurricanes San Felipe and San Ciprían. Moreover, hurricane María coincided with social stressors such as economic bankruptcy and unprecedented corruption in the governance of the island, which suggests that all sectors of SETS are poised for another round of change and innovation, including the ecological systems.

\section{Final Reflection}

The review of the literature on extreme disturbance events, including the effects of hurricane María on the Puerto Rico SETS, supports three propositions with significant implications to the study and 
understanding of SETS. First, extreme disturbance events are of such power and complexity that they can influence the level and kind of relationship between humans and their environment. As a result, anthropogenic modifications of the environment through their effect on ecesis can dictate the composition of the species assemblages that emerge through succession after extreme disturbance events. This means that human reaction to extreme disturbance events can influence the structure and species composition of the ecological systems of SETS, which ecologists have studied as if they were disconnected from human activity. Second, the human legacy on novel forests is so strong that even extreme disturbance events such as hurricanes cannot alter the succession trajectory originally impulsed by anthropogenic effects such as eroded soils (Thompson and others 2002, 2007; Uriarte and others 2009). Human legacies cannot be ignored when studying and analyzing ecosystems. Third, it appears that the species composition and functioning of novel forests is tied to economic activity in the social and technological sectors of SETS. Such interactions observed in the Puerto Rico SETS reflect a well-integrated system of humans and non-humans functioning in the context of periodic extreme disturbance events. These propositions have in common the close nexus between anthropogenic and non-anthropogenic forces and their effects on ecosystems; it is no longer possible to analyze one without consideration of the other.

\section{ACKNOWLEDGEMENTS}

This work was conducted in collaboration with the University of Puerto Rico and the Urban Resilience to Extremes Sustainability Research Network (UREx SRN) under National Science Foundation Grant AGS-1444755. Gisel Reyes and Jorge Morales helped with the literature search. Odalys Martínez provided climatic data, and K. Stephen Hughes provided landslide area data. The comments of Tischa Muñoz Erickson, Tana Wood, Ashley Van Beusekom, and four journal reviewers improved the manuscript.

\section{OPEN ACCESS}

This article is licensed under a Creative Commons Attribution 4.0 International License, which permits use, sharing, adaptation, distribution and reproduction in any medium or format, as long as you give appropriate credit to the original author(s) and the source, provide a link to the Creative
Commons licence, and indicate if changes were made. The images or other third party material in this article are included in the article's Creative Commons licence, unless indicated otherwise in a credit line to the material. If material is not included in the article's Creative Commons licence and your intended use is not permitted by statutory regulation or exceeds the permitted use, you will need to obtain permission directly from the copyright holder. To view a copy of this licence, visit $h$ ttps://creativecommons.org/licenses/by/4.0/

\section{REFERENCES}

Achmon Y, Achmon M, Dowdy FR, Spiegel O, Claypool JT, Toniato J, Simmons CW. 2018. Understanding the Anthropocene through the lens of landfill microbiomes. Front Ecol Environ 16:354-60. https://doi.org/10.1002/fee.1819.

Barreto Orta M, Méndez Tejeda R, Rodríguez E, Cabrera N, Díaz E, Pérez K. 2019. State of the beaches in Puerto Rico after Hurricane Maria (2017). Shore Beach 87:16-23.

Barrett GW, Rosenberg R, Eds. 1981. Stress effects on natural ecosystems. Chichester: Wiley. p 305.

Bessette-Kirton EK, Cerovski-Darriau C, Schulz WH, Coe JA, Kean JW, Godt JW, Thomas MA, Hughes KS. 2019. Landslides triggered by hurricane Maria: assessment of an extreme event in Puerto Rico. GSA Today. Boulder: The Geological Society of America. https://doi.org/10.1130/gsatg383a.1

Biggs R, Schlüter M, Schoon ML, Eds. 2015. Principles for building resilience: sustaining ecosystem services in socialecological systems. Cambridge: Cambridge University Press.

Boose ER, Foster DR, Fluet M. 1994. Hurricane impacts to tropical and temperate forest landscapes. Ecol Monogr 64:369-400.

Bouskill NJ, Wood TE, Baran R, Hao Z, Ye Z, Bowen BP, Lim HC, Nico PS, Holman H-Y, Gilbert B, Silver WL, Northen TR, Brodie EL. 2016. Belowground response to drought in a tropical forest soil. II. Change in microbial function impacts carbon composition. Front Microbiol. https://doi.org/10.3389 /fmicb.2016.00323.

Brock EK. 2015. Money trees The Douglas fir and American forestry, 1900-1944. Corvallis: Oregon State University Press.

Brokaw NVL. 1985. Treefalls, regrowth, and community structure in tropical forests. In: Pickett STA, White PS, Eds. The ecology of natural disturbance and patch dynamics. Orlando, FL: Academic Press Inc. p 53-69.

Brokaw N, Zimmerman JK, Willig MR, Camilo GR, Covich AP, Crowl TA, Fetcher N, Haines BL, Lodge DJ, Lugo AE, Myster RW, Pringle CM, Sharpe JM, Scatena FN, Schowalter TD, Silver WL, Thompson J, Vogt DJ, Vogt KA, Waide RB, Walker LR, Woolbright LL, Wunderle JM, Zou X. 2012. Response to disturbance. In: Brokaw N, Crowl TA, Lugo AE, McDowell WH, Scatena FN, Waide RB, Willig MR, Eds. A Caribbean forest tapestry: the multidimensional nature of disturbance and response. New York, NY: Oxford University Press. p 20171.

Bull JW, Maron M. 2016. How humans drive speciation as well as extinction. Proc R Soc B 283:20160600. https://doi.org/10. 1098/rspb.2016.0600.

Canals Silander MF, García Moreno CG. 2019. On the spatial distribution of the wave energy resource in Puerto Rico and 
the United States Virgin Islands. Renew Energy 136:442-51. h ttps://doi.org/10.1016/j.renene.2018.12.120.

Carpenter S, Walker B, Anderies JM, Abel N. 2001. From metaphor to measurement: resilience of what to what? Ecosystems 4:765-81.

Carpenter SR, Westley F, Turner MG. 2005. Surrogates for resilience of social-ecological systems. Ecosystems 8:941-4.

Chapin FSIII, Robards MD, Johnstone JF, Lantz TC, Kokelj SV. 2013. Case study: novel socio-ecological systems in the north: potential pathways toward ecological and social resilience. In: Hobbs RJ, Higgs ES, Hall CM, Eds. Novel ecosystems: Intervening in the new ecological world order. Chichester: Wiley. p 334-44.

Clements FE. 1928. Plant succession and indicators. A definitive edition of plant succession and plant indicators. New York, NY: Hafner Press.

Clements FE. 1935. Experimental ecology in the public service. Ecology 16:342-63.

Clements FE, Shelford VE. 1939. Bio-ecology. New York, NY: Wiley.

Coleman DC. 2010. Big ecology. The emergence of ecosystem science. Berkeley, CA: University of California Press. p 236.

Colón Torres JA. 2009. Climatología de Puerto Rico. Río Piedras, PR: La Editorial de la Universidad de Puerto Rico.

Cox GW. 2004. Alien species and evolution. The evolutionary ecology of exotic plants, animals, microbes, and interacting native species. Washington, DC: Island Press.

Crausbay SD, Ramirez AR, Carter SL, Cross MS, Hall KR, Bathke DJ, Betancourt JL, Colt S, Cravens AE, Dalton MS, Dunham JB, Hay LE, Hayes MJ, McEvoy J, McNutt CA, Moritz MA, Nislow KH, Raheem N, Sanford T. 2017. Defining ecological drought for the twenty-first century. Bull Am Meteorol Soc 12:2543-50. https://doi.org/10.1175/BAMS-D_16-0292.1.

Dale VH, Lugo AE, MacMahon JA, Pickett STA. 1998. Ecosystem management in the context of large, infrequent disturbances. Ecosystems 1:546-57.

Dale VH, Swanson FJ, Crisafulli CM, Eds. 2005. Ecological responses to the 1980 eruption of Mount St. Helens. New York, NY: Springer. p 342.

Ellis EC. 2015. Ecology in an anthropogenic biosphere. Ecological Monographs 85:287-331.

Evans F. 1956. Ecosystem as the basic unit in ecology. Science 123:1127-8.

Ewel JJ. 1971. Experiment in arresting succession with cutting and herbicides in five tropical environments. Dissertation. University of North Carolina, Chapel Hill, NC.

Fernandez Vega J, Covey KR, Ashton MS. 2017. Tamm review: large-scale infrequent disturbances and their role in regenerating shade-intolerant tree species in Mesoamerican rainforests: implications for sustainable forest management. For Ecol Manag 395:48-68.

Fleischman FD, Ban NC, Evans LS, Epstein G, Garcia-Lopez G, Villamayor-Tomas S. 2014. Governing large-scale social-ecological systems: Lessons from five cases. Int $\mathrm{J}$ Commons 8:428-56. https://doi.org/10.18352/ijc.416.

Foster DR, Knight DH, Franklin JF. 1998. Landscape patterns and legacies resulting from large, infrequent forest disturbances. Ecosystems 1:497-510.

Frederick KD, Sedjo RA, Eds. 1991. America's renewable resources. Historical trends and current challenges. Washington DC: Resources for the Future. p 296.
Golley FB. 1993. A history of the ecosystem concept in ecology: more than the sum of the parts. New Haven, CN: Yale University Press.

Grotjahn R, Barlow M, Black R, Cavazos T, Gutowski W, Gyakum J, Katz R, Kumar A, Leung L-Y, Schumacher R, Wehner M. 2014. US CLIVAR workshop on analyses, dynamics, and modeling of large-scale meteorological patterns associated with extreme temperature and precipitation events. US CLIVAR Report 2014-2, US CLIVAR Project Office, Washington, DC.

Grove M, Ogden L, Pickett S, Boone C, Buckley G, Locke DH, Lord C, Hall B. 2018. The legacy effect: understanding how segregation and environmental injustice unfold over time in Baltimore. Ann Am Assoc Geogr 108:524-37.

Gunderson LH, Holling CS, Allen CR. 2010. The evolution of an idea- the past, present, and future of ecological resilience. In: Gunderson LH, Allen CR, Holling CS, Eds. Foundations of ecological resilience. Washington, D.C: Island Press. p 423-44.

Gunderson LH, Pritchard L Jr, Eds. 2002. Resilience and the behavior of large-scale systems. Washington, DC: Island press.

Harley MD, Turner IL, Kinsela MA, Middleton JH, Mumford PJ, Splinter KD, Phillips MS, Simmons JA, Hanslow DJ, Short AD. 2017. Extreme coastal erosion enhanced by anomalous extratropical storm wave direction. Sci Rep 7:6033. https://d oi.org/10.1038/s41598-017-05792-1.

Heartsill Scalley T. 2017. Insights on forest structure and composition from long-term research in the Luquillo Mountains. Forests 8:204.

Hobbs RJ, Valentine LF, Standish RJ, Jackson ST. 2018. Movers and stayers: novel assemblages in changing environments. Trends in Ecol Evol 33:116-28. https://doi.org/10.1016/j.tree 2017.11.001.

Holling CS. 1973. Resiliency and stability of ecological systems. Annu Rev Ecol Syst 4:1-23.

Holling CS. 1996. Engineering resilience versus ecological resilience. In: Schulze PC, Ed. Engineering within ecological constraints. Washington, DC: National Academy Press. p $31-$ 44.

Holling CS, Gunderson LH. 2002. Resilience and adaptive cycles. In: Gunderson LH, Holling CS, Eds. Panarchy: understanding transformations in human and natural systems. Washington DC: Island Press. p 25-62.

Holling CS, Gunderson LH, Peterson GD. 2002. Sustainability and panarchies. In: Gunderson LH, Holling CS, Eds. Panarchy understanding transformations in human and natural systems. Washington, DC: Island Press. p 63-102.

Hopkinson C, Lugo AE, Alber M, Covich AP, Van Bloem SJ. 2008. Understanding and forecasting the effects of sea level rise and intense windstorms on coastal and upland ecosystems: the need for a continental-scale observatory network. Front Ecol Environ 6:255-63.

$\mathrm{Hu}$ T, Smith RB. 2018. The impact of hurricane María on the vegetation of Dominica and Puerto Rico using multispectral remote sensing. Remote Sens 10:827.

Johnson EA, Miyanishi K, Eds. 2007. Plant disturbance ecology. The process and the response. Amsterdam: Elsevier/Academic Press.

Johnstone JF, Allen CD, Franklin JF, Frelich LE, Harvey BJ, Higuera PE, Mack MC, Meentemeyer RK, Metz MR, Perry GLW, Schoennagel T, Turner MG. 2016. Changing disturbance regimes, ecological memory, and forest resilience. Front Ecol Environ 14:369-78. https://doi.org/10.1002/fee.1311. 
Keelings D, Hernández Ayala JJ. 2019. Extreme rainfall associated with hurricane Maria over Puerto Rico and its connections to climate variability and change. Geophys Res Lett 46:2964-73. https://doi.org/10.1029/2019GL082077.

Kingsland SE. 2005. The evolution of American ecology, 18902000. Baltimore: The Johns Hopkins University Press. p 313.

Kishore N, Marqués D, Mahmud A, Kiang MV, Rodriguez I, Fuller A, Ebner P, Sorensen C, Racy F, Lemery J, Maas L, Leaning J, Irizarry RA, Balsari S, Buckee CO. 2018. Mortality in Puerto Rico after hurricane Maria. New Engl J Med 379:162-70. https://doi.org/10.1056/NEJMsal 803972.

Klein Tank AMG, Zwiers FW, Zhang X. 2009. Guidelines on analysis of extremes in a changing climate in support of informed decisions for adaptation. Climate Data and Monitoring WCDMP-No. 72, World Meteorological Organization, Geneva, Switzerland.

Levitt J. 1980. Responses of plants to environmental stresses. Water, radiation, salt, and other stresses. 2nd edn. New York, NY: Academic Press.

Lin N, Kopp RE, Horton BP, Donnelly JP. 2016. Hurricane Sandy's flood frequency increasing from year 1800 to 2100 . Proc Nat Acad Sci . https://doi.org/10.1073/pnas.1604386113.

Lugo AE. 1978. Stress and ecosystems. In: Thorp JH, Gibbons JW, Eds. Energy and environmental stress in aquatic systems. Springfield, VA: National Technical Information Services. $p$ 62-101.

Lugo AE. 2005. Los bosques. In: Joglar RL, Ed. Biodiversidad de Puerto Rico. San Juan, PR: Vertebrados terrestres y ecosistemas. Editorial del Instituto de Cultura Puertorriqueña. $p$ 395-548.

Lugo AE. 2008. Visible and invisible effects of hurricanes on forest ecosystems: an international review. Austral Ecol 33:368-98.

Lugo AE. 2018. Characterization of ten extreme disturbance events in the context of social and ecological systems. Biogeochemistry 141:385-400. https://doi.org/10.1007/s10533-0 18-0453-y.

Lugo AE. 2019. Social-ecological-technological effects of hurricane María on Puerto Rico Planning for resilience under extreme events. Cham: Springer. https://doi.org/10.1007/978-3030-02387-4

Lugo AE, Helmer E. 2004. Emerging forests on abandoned land: Puerto Rico's new forests. For Ecol Manag 190:145-61.

Lugo AE, Zimmerman JK. 2002. Ecological life histories. In: Vozzo JA, Ed. Tropical tree seed manual. Agriculture Handbook 721. Washington, DC: USDA Forest Service. p 191-213.

Lugo AE, Winchell KM, Carlo TA. 2018. Novelty in ecosystems. In: DellaSala DA, Goldstein MI, Eds. The Encyclopedia of the Anthropocene. Oxford: Elsevier. p 259-71.

Lugo AE, Abelleira Martínez OL. 2018. Stoichiometry of decomposing Spathodea campanulata leaves in novel puertorrican forests. For Ecol Manag 430:176-87. https://doi.org/10. 1016/j.foreco.2018.07.059.

Lugo AE, Brown S, Brinson MM. 1990. Concepts in wetland ecology. In: Lugo AE, Brinson MM, Brown S, Eds. Forested wetlands. New York, NY: Elsevier. p 53-85.

Magnani MB, Blanpied ML, DeShon HR, Hornbach MJ. 2017. Discriminating between natural versus induced seismicity from long-term deformation history of intraplate faults. Sci Adv 3(e1701593):1-12.

Markolf SA, Chester MV, Eisenberg DA, Iwaniec DM, Davidson CI, Zimmerman R, Miller TR, Ruddell BL, Chang H. 2018.
Interdependent infrastructure as linked social, ecological, and technological systems (SETSs) to address lock-in and enhanced resilience. Earth's Future 6:1638-59. https://doi.org/ 10.1029/2018EF000926.

Martinuzzi S, Lugo AE, Brandeis TJ, Helmer EH. 2013. Geographic distribution and level of novelty of Puerto Rican forests. In: Hobbs RJ, Higgs ES, Hall C, Eds. Novel ecosystems: intervening in the new ecological world order. Oxford: Wiley. p 81-7.

McPhillips LE, Chang H, Chester MV, Depietri Y, Friedman E, Grimm NB, Kominoski JS, McPhearson T, Méndez-Lázaro P, Rosi EJ, Shiva JS. 2018. Defining extreme events: a crossdisciplinary review. Earth's Future 6:441-55. https://doi.org/ 10.1002/2017EF000686.

Méndez Lázaro PA, Pérez Cardona CM, Rodríguez E, Martínez O, Taboas M, Bocanegra A, Méndez Tejeda R. 2016. Climate change, heat, and mortality in the tropical urban area of San Juan. Puerto Rico. Int J Biometeorol . https://doi.org/10.1007/ s00484-016-1291-z.

Miller PW, Kumar A, Mote TL, Moraes FDS, Mishra DR. 2019. Persistent hydrological consequences of hurricane Maria in Puerto Rico. Geophys Res Lett 46:1413-22. https://doi.org/10. 1029/2018GL081591.

Monroe JG, Markman DW, Beck WS, Felton AJ, Vahsen ML, Pressler Y. 2018. Evolutionary dynamics of carbon cycling in the Anthropocene. Trends Ecol Evol 33:213-25. https://doi. org/10.1016/j.tree.2017.12.006.

Odum EP. 1969. The strategy of ecosystem development. Science 164:262-70.

Odum HT. 1983. Systems ecology. New York, NY: Wiley.

Odum HT. 1996. Environmental accounting. EMERGY and environmental decision making. New York, NY: Wiley.

Pasch RJ, Penny AB, Berg R. 2018. National Hurricane Center tropical cyclone report: hurricane Maria. Miami, FL: National Oceanic and Atmospheric Administration, Department of Commerce, National Weather Service.

Peters DPC, Lugo AE, Chapin-III SS, Pickett STA, Duniway M, Rocha AV, Swanson FJ, Laney C, Jones J. 2011. Cross-system comparisons elucidate disturbance complexities and generalities. Ecosphere 2: Article 81.

Peterson TC, Hoerling MP, Stott PA, Editors SH. 2013. Explaining extreme events of 2012 from a climatic perspective. Bull Am Meteorol Soc 94:S1-74.

Pickett STA, White PS, Eds. 1985. The ecology of natural disturbance and patch dynamics. Orlando, FL: Academic Press. $p$ 472.

Pickett STA, Kolasa J, Armesto JJ, Collins SL. 1989. The ecological concept of disturbance and its expression at various hierarchical levels. Oikos 54:129-36.

Radeloff VC, Williams JW, Bateman BL, Burke KD, Carter SK, Childress ES, Cromwell KJ, Gratton C, Hasley AO, Kraemer BM, Latzka AW, Marin-Spiotta E, Meine CD, Munoz SE, Neeson TM, Pidgeon AM, Rissman AR, Rivera RJ, Szymanski LM, Usinowicz J. 2015. The rise of novelty in ecosystems. Ecol Appl 25:2051-68.

Ratajczak Z, Carpenter SR, Ives AR, Kucharik CJ, Ramiadantsoa T, Stegner MA, Williams JW, Zhang J, Turner MG. 2018. Abrupt change in ecological systems: inference and diagnosis. Trends Ecol Evol 33:513-26. https://doi.org/10.1016/j.tree.2 018.04.013.

Raup HM. 1941. Botanical problems in boreal America. Bot Rev 7:147-248. 
Redman CL. 2014. Should sustainability and resilience be combined or remain distinct pursuits? Ecol Soc 19:37. https://doi. org/10.5751/ES-06390-190237.

Roberts RC. 1942. Soil survey of Puerto Rico. USDA Series 1936, No. 8. US. Printing Office, Washington, DC.

Román MO, Stokes EC, Shrestha R, Wang Z, Schultz L, Sepúlveda Carlo EA, Sun Q, Bell J, Molthan A, Kalb V, Ji C, Seto KC, McClain SN, Enenkel M. 2019. Satellite-based assessment of electricity restoration efforts in Puerto Rico after hurricane Maria. PLoS ONE 14:e0218883. https://doi.org/10.1371/jour nal.pone.0218883.

Romero-Lankao P, Gnatz DM, Wilhelmi O, Hayden M. 2016. Urban sustainability and resilience: from theory to practice. Sustainability 8(12):1224. https://doi.org/10.3390/s u8121224.

Scatena FN, Larsen MC. 1991. Physical aspects of Hurricane Hugo in Puerto Rico. Biotropica 23:317-23.

Scatena FN, Doherty SJ, Odum HT, Kharecha P. 2002. An EMERGY evaluation of Puerto Rico and the Luquillo Experimental Forest. USDA Forest Service, International Institute of Tropical Forestry General Technical Report IITF-GTR-9, Río Piedras, PR.

Scatena FN, Moya S, Estrada C, Chinea JD. 1996. The first five years in the reorganization of aboveground biomass and nutrient use following Hurricane Hugo in the Bisley Experimental Watersheds, Luquillo Experimental Forest, Puerto Rico. Biotropica 28:424-40.

Sepúlveda Rivera A. 2018. La resiliencia ante la emergencia urbana: Quique, el Papa y tú. PowerPoint. San Juan, PR: Scuba Dogs Society.

Silver WL, Brown S, Lugo AE. 1996. Biodiversity and biogeochemical cycles. In: Orians G, Dirzo R, Cushman JH, Eds. Biodiversity and ecosystem process in tropical forests. Heidelberg: Springer. p 49-67.

Soil Conservation Service. 1967. Soil survey laboratory data and description for some soils of Puerto Rico and the Virgin Islands. USDA Soil Survey Investigations Report No. 12, San Juan, PR.

Sousa WP. 1984. The role of disturbance in natural communities. Annu Rev Ecol Syst 15:353-91.

Sterner RW, Elser JJ. 2002. Ecological stoichiometry: the biology of elements from molecules to the biosphere. Princeton, NJ: Princeton University Press.

Stocker TF, Qin D, Plattner G-K, Tignor M, Allen SK, Boschung J, Nauels A, Xia Y, Bex V, Midgley PM, Eds. 2014. IPCC 2013: Climate change 2013: the physical science basis. Cambridge: Cambridge University Press. p 1535.

Stockwell CA, Hendry AP, Kinnison MT. 2003. Contemporary evolution meets conservation biology. Trends Ecol Evol 18:94-101. https://doi.org/10.1016/S0169-5347(02)00044-7.

Tansley AG. 1935. The use and abuse of vegetational concepts and terms. Ecology 16:284-307.
Thomas CD. 2015. Rapid acceleration of plant speciation during the Anthropocene. Trends Ecol Evol 30:448-55.

Thompson J, Lugo AE, Thomlinson J. 2007. Land use history, hurricane disturbance, and introduced species survival in a subtropical wet forest in Puerto Rico. Plant Ecol 192:289-301.

Thompson J, Brokaw N, Zimmerman JK, Waide RB, Everham EMIII, Lodge DJ, Taylor CM, García Montiel D, Fluet M. 2002. Land use history, environment, and tree composition in a tropical forest. Ecol Appl 12:1344-63.

Turner MG, Donato DC, Romme WH. 2013. Consequences of spatial heterogeneity for ecosystem services in changing forest landscapes: priorities for future research. Landsc Ecol 28:1081-97. https://doi.org/10.1007/s10980-012-9741-4.

Turner MG, Dale VH. 1998. Comparing large infrequent disturbances: what have we learned? Ecosystems 1:493-6.

Uriarte M, Canham CD, Thompson J, Zimmerman JK, Murphy L, Sabat AM, Fetcher N, Haines B. 2009. Natural disturbance and human landuse as determinants of tropical forest dynamics: results from a forest simulator. Ecol Monogr 79:423-43.

Uriarte M, Thompson J, Zimmerman JK. 2019. Hurricane María tripled stem breaks and doubled tree mortality relative to other major storms. Nat Commun. www.nature.com/naturec ommunications, https://doi.org/10.1038/s41467-019-093192.

Van Beusekom AE, Álvarez-Berrios NL, Gould WA, Quiñones M, González G. 2018. Hurricane María in the U.S. Caribbean: disturbance forces, variation of effects, and implications for future storms. Remote Sens 10:3390. https://doi.org/10.3390/ rs 100913886.

Weaver PL, Birdsey RA, Lugo AE. 1987. Soil organic matter in secondary forests of Puerto Rico. Biotropica 19:17-23.

Westley F. 2002. The devil in the dynamics: adaptive management on the front lines. In: Gunderson LH, Holling CS, Eds. Panarchy; understanding transformations in human and natural systems. Washington, DC: Island Press. p 333-60.

White PS. 1979. Pattern, process and natural disturbance in vegetation. Bot Rev 45:229-99.

White PS, Pickett STA. 1985. Natural disturbance and patch dynamics: an introduction. In: Pickett STA, White PS, Eds. The ecology of natural disturbance and patch dynamics. New York, NY: Academic Press. p 3-13.

Whittaker RH. 1953. A consideration of climax theory: the climax as a population and pattern. Ecol Monogr 23:41-78.

Wilkinson DM. 1999. The disturbing history of intermediate disturbance. Oikos 84:145-7. https://doi.org/10.2307/354687 4.

Zhang X, Alexander L, Hegerl GC, Jones P, Tank AK, Peterson TC, Trewin B, Zwiers FW. 2011. Indices for monitoring changes in extremes based on daily temperature and precipitation data. WIREs Clim Change . https://doi.org/10.1002/ wcc. 147. 